\title{
Stilbenoids: A Natural Arsenal against Bacterial Pathogens
}

\author{
Luce Micaela Mattio $₫$, Giorgia Catinella, Sabrina Dallavalle * and Andrea Pinto® \\ Department of Food, Environmental and Nutritional Sciences (DeFENS), University of Milan, Via Celoria 2, \\ 20133 Milan, Italy; luce.mattio@unimi.it (L.M.M.); giorgia.catinella@unimi.it (G.C.); andrea.pinto@unimi.it (A.P.) \\ * Correspondence: sabrina.dallavalle@unimi.it
}

Received: 18 May 2020; Accepted: 16 June 2020; Published: 18 June 2020

\begin{abstract}
The escalating emergence of resistant bacterial strains is one of the most important threats to human health. With the increasing incidence of multi-drugs infections, there is an urgent need to restock our antibiotic arsenal. Natural products are an invaluable source of inspiration in drug design and development. One of the most widely distributed groups of natural products in the plant kingdom is represented by stilbenoids. Stilbenoids are synthesised by plants as means of protection against pathogens, whereby the potential antimicrobial activity of this class of natural compounds has attracted great interest in the last years. The purpose of this review is to provide an overview of recent achievements in the study of stilbenoids as antimicrobial agents, with particular emphasis on the sources, chemical structures, and the mechanism of action of the most promising natural compounds. Attention has been paid to the main structure modifications on the stilbenoid core that have expanded the antimicrobial activity with respect to the parent natural compounds, opening the possibility of their further development. The collected results highlight the therapeutic versatility of natural and synthetic resveratrol derivatives and provide a prospective insight into their potential development as antimicrobial agents.
\end{abstract}

Keywords: antibacterial activity; infectious diseases; stilbenoids; resveratrol derivatives; natural compounds

\section{Introduction}

Natural products produced by living organisms, such as plants, fungi, bacteria, insects, sponges, and large animals as means of defence against pathogens and stress factors, have always been a source of inspiration for new drugs. Natural products constitute privileged structures in terms of chemical and biological space, which have been optimised after millennia of evolutionary pressure [1-3]. The antibiotic era started with Fleming's discovery of the natural penicillins, which was firstly isolated from the fungus Penicillium chrysogenum, followed by aminoglycosides, cephalosporins, glycopeptides, macrolides, rifamycins, and tetracyclines [4]. To date, these natural product scaffolds are still valid lead compounds in the antibiotic research. Newman and Cragg [5] reported that in the last 40 years, 162 molecules were introduced as antibacterial agents: besides 4 biologics and the 32 vaccines, only 36 molecules are completely synthetic, mainly belonging to the quinolones family. Interestingly, quinolones derive from nalidixic acid, a by-product generated in the synthesis of derivatives of the natural compound quinine [4]. The remaining 90 antibacterial molecules, accounting for over $55 \%$ of the total, include 11 natural products, 78 semi-synthetic derivatives, and 1 synthetic compound containing a nature-inspired pharmacophore (bromodimoprin), confirming the key role that nature is still playing as source of new scaffolds for this class of drugs [5].

Stilbenoids represent an attractive class of plant polyphenols that are widely present in nature and largely studied in the last decades because of their different bioactivities such as anti-inflammatory, 
neuroprotective, anticancer, antimicrobial, and antidiabetic effects [6]. Stilbenoids are both woody constitutive metabolites and phytoalexins, which are substances produced by plants as means of protection against microbial infections and stress factors [7]. Stilbenoids biosynthesis occurs via the phenylpropanoid pathway: phenylalanine is converted into a cinnamate derivative, which, after activation into cinnamoyl-CoA by CoA-ligase, undergoes the enzymatic reaction of stilbene synthase to give the stilbenoid scaffold that can be further processed by several reactions such as glycosylation, methylation, prenylation, and oxidative couplings $[6,8]$. From a biochemical point of view, stilbenoids, including stilbenes, 2-aryl benzofurans, phenanthrenes, and related compounds, derive from the same biosynthesis pathway [9]. From a chemical point of view, stilbenoids share the stilbene backbone, consisting of two differently substituted aromatic rings, which is linked by an ethylene bridge, the E-configuration being the most common and stable in nature [9]. The aromatic rings differ in the number and position of functional groups, including hydroxy, methoxy, prenyl, geranyl, or farnesyl moieties. Moreover, stilbenoids can be classified as monomers or oligomers, which are isolated as aglycones or glycosides [6]. The most studied stilbenoid is resveratrol (Figure 1), which has been extensively investigated for its numerous potential health benefits [10]. However, resveratrol-derived monomers, dimers, and oligomers are endowed with multifaceted biological activities as well [6].

This review provides an overview of recent literature on the antibacterial potential of natural and nature-inspired stilbenoids, focusing on mechanisms of action, structure-activity relationship (SAR) studies, combination therapies, and potential applications in the medicinal and food chemistry field.

\section{Monomeric Stilbenoids}

\subsection{Resveratrol}

Resveratrol (3, 5, 4' -trihydroxystilbene) (Figure 1) is a natural phytoalexin that was first discovered in the roots of the white hellebore of Veratrum grandiflorum and then isolated from several plants and fruits, such as grapes, apples, berries, pistachios, and peanuts. Several experimental and preclinical studies attributed cardioprotective, cancer chemopreventive, anti-inflammatory, and antidiabetic effects to this molecule [10]. Resveratrol was tested on many different microorganisms for its antibacterial activity.

In a recent review, Vestergaard et al. [11] described the multiple targets potentially involved in bacterial growth inhibition displayed by resveratrol. Resveratrol can reversibly bind to ATP synthase in the aerobic E. coli ( $\mathrm{IC}_{50}$, concentration of inhibitor where $50 \%$ of maximal inhibition was observed $=94 \mu \mathrm{M}$ ), and in Mycobacterium smegmatis $\left(\mathrm{IC}_{50}=50 \mu \mathrm{M}\right)$, thus reducing their cellular energy production and inhibiting their proliferation. Moreover, in E. coli, resveratrol was found to inhibit oxidative phosphorylation. In E. Coli mutans, lacking ATP synthase, resveratrol at a concentration of $228 \mu \mathrm{g} / \mathrm{mL}$ seemed to interfere with cell division, probably by the suppression of FtsZ, which is a key protein involved in septum formation during cell division. In addition, E. coli cells treated with $182 \mu \mathrm{g} / \mathrm{mL}$ resveratrol showed potassium leakage and propidium uptake, indicating membrane damage, whereas $S$. aureus species did not show membrane damage [11]. Resveratrol may also cleave the DNA, generating a $\mathrm{Cu}$ (II)-peroxide complex that binds to DNA to form a DNA-resveratrol-Cu(II) ternary complex. Through the reduction of $\mathrm{Cu}(\mathrm{II})$ to $\mathrm{Cu}(\mathrm{I})$, DNA cleavage occurs. In this mechanism, the 4-hydroxy group is fundamental in the reduction of copper, because of its pro-oxidant activity. As proof of concept, isoresveratrol (Figure 1), an analogue of resveratrol bearing an hydroxyl group in the meta position in place of the para position, is not able to reduce $\mathrm{Cu}(\mathrm{II})$ and to cause DNA cleavage. Moreover, the olefinic bridge plays a key role, providing the planarity to bind efficiently DNA and to stabilise the 4-oxy radical form. Conversely, dihydroresveratrol (Figure 1) showed a decreased ability of DNA cleavage [12]. 

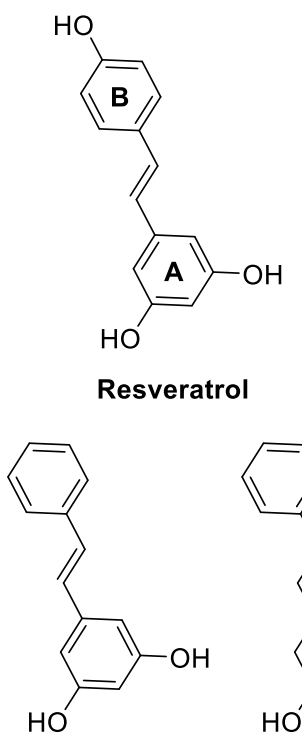

Pinosylvin<smiles>COc1cc(/C=C/c2cc(O)cc(O)c2)ccc1O</smiles>

Isorhapontigenin

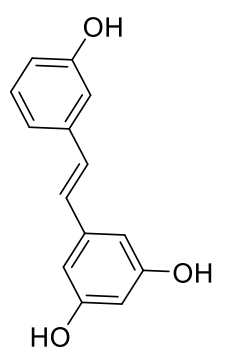

Isoresveratrol

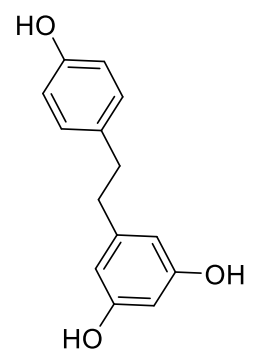

Dihydroresveratrol

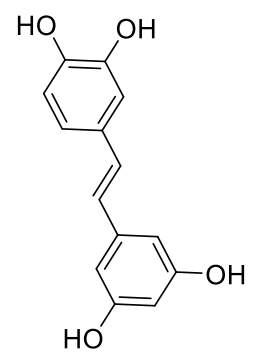

Piceatannol $\mathrm{MeO}$
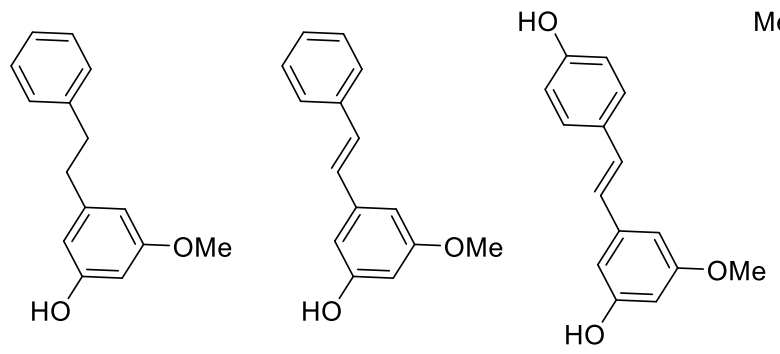

\section{Pinosylvin} monomethylether monomethylether<smiles>COc1ccc(/C=C/c2cc(O)cc(O)c2)cc1O</smiles>

Rhapontigenin

$\mathrm{MeO}$

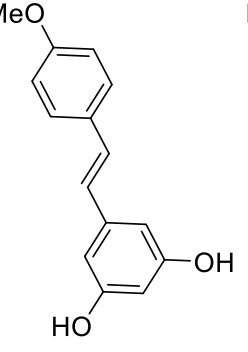

Desoxyrhapontigenin

\section{Pinostilbene}

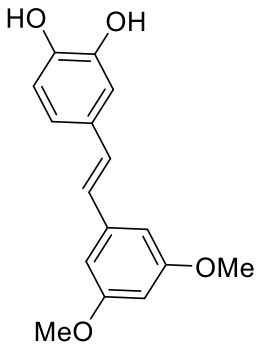

3'-Hydroxypterostilbene

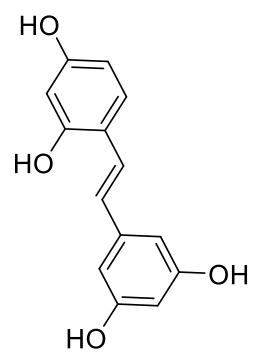

Oxyresveratrol $\mathrm{HO}$<smiles>COc1cc(/C=C/c2ccc(O)cc2)cc(OC)c1</smiles>

3,4'-Dimethoxy resveratrol

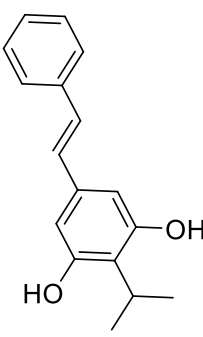

3,5-Dihydroxy- 3,5-Dihydroxy4-isopropyl- 4-ethyl-transtrans-stilbene stilbene<smiles>COc1ccc(/C=C/c2cc(OC)cc(OC)c2)cc1</smiles>

4'-Bromo resveratrol 4,4'-Dihydroxy stilbene (DHS) Triacetylresveratrol

Trimethylresveratrol<smiles>CC(C)c1c(O)cc(/C=C/c2ccccc2)cc1O</smiles>

3,5-Dihydroxy4-isopropyl-trans-stilbene<smiles></smiles>

2-Isopropyl-5(3,phenyl-oxyranyl)benzene-1,3-diol<smiles>COc1cc(/C=C/c2ccc(O)cc2)cc(OC)c1</smiles>

$3,5,4$ '-Trihydroxy-stilbene3,5-O- $\beta$-D-diglucopyranoside

Figure 1. Structures of monomeric stilbenoids.

In a study on the two Gram-negative Arcobacter butzleri and Arcobacter cryaerophilus [13], which are commonly found in contaminated food and water and are consequently associated with human and animal infections [14], resveratrol exerted bacteriostatic and bactericidal activity by different mechanisms of action, with minimum inhibitory concentration (MIC) values of $50-100 \mu \mathrm{g} / \mathrm{mL}$. The DNA-specific fluorescent stain DRAQ5 revealed a reduced content of DNA in the treated bacterial cultures, highlighting the action of resveratrol on DNA synthesis. The decrease of metabolic activity 
and intracellular DNA content occurred before the membrane alteration, which was observed by SEM (scanning electron microscopy), suggesting that in this case, resveratrol did not target directly the membrane but acted on several cellular functions that eventually led to cell division impairment and death. Moreover, resveratrol showed a partial activity as efflux pump inhibitor (EPI) in the ethidium bromide (EtBr) accumulation assays. On the other hand, the presence of the effective EPI PA $\beta N$ (L-phenylalanine-L-arginine- $\beta$-naphthylamide) enhanced the susceptibility to resveratrol with the reduction of MIC values by 16 -fold and fourfold in A. butzleri and A. cryaerophilus, respectively. This result revealed the high contribution of efflux pumps to resistance to the polyphenol in Arcobacter spp [13]. Resveratrol antivirulence properties were demonstrated on several microorganisms [11,15]. Virulence is the ability of a pathogen to cause damage to a host through virulence factors (e.g., toxins) or the mechanism of infection (factors for adhesion, invasion, colonisation, and biofilm production). Therefore, the pathogen left without these abilities is not able to harm the host anymore $[16,17]$. Resveratrol inhibited biofilm formation in Gram-negative bacteria, such as Fusobacterium nucleatum, $V$. cholerae, P. aeruginosa, and E. coli, as well as in the Gram-positive P. acnes [11]. Through the downregulation of motility and flagella genes, resveratrol inhibited the motility in P. mirabilis, E. coli, and Vibrio vulnificus. In V. vulnificus, resveratrol reduced the expression of the toxin RtxA1, implicated in mice lethality, at 10-30 $\mu \mathrm{M}$ concentration, whereas in $V$. cholerae, resveratrol directly bound cholera toxin (CT) and prevented the toxin endocytosis into host cells at 300-400 $\mu \mathrm{M}$ concentration [11]. Moreover, in a recent study, resveratrol was found to inhibit at $32 \mu \mathrm{g} / \mathrm{mL}$ (concentration eightfold lower than MIC) the expression of alpha-hemolysin (Hla), which is a toxin secreted by several pathogenic $S$. aureus strains to create a pore in target cells, leading to membrane damages and cell death. In particular, RT-PCR assays revealed that the transcription levels of hla (encoding Hla) and RNAIII, the effector molecules of the accessory gene regulator (agr) locus, were reduced by 5.76 fold and 3.57 fold, respectively. In vitro studies on S. aureus-infected A459 cells verified that resveratrol at $32 \mu \mathrm{g} / \mathrm{mL}$ was able to alleviate the injury caused by S. aureus. Further, the in vivo experiments on mice with $S$. aureus pneumonia confirmed that resveratrol was able to reduce the mortality rate of infected mice by decreasing inflammatory reactions and bacterial burden in their lungs [18]. In Yersinia enterolitica, Erwinia carotovora, E. coli, and Chromobacterium violaceum, resveratrol $(5-20 \mu \mathrm{g} / \mathrm{mL})$ was also found to interfere with quorum sensing (QS) releasing factors [11]. These chemical signaling molecules (autoinducers) are produced by bacteria proportionally to cell density in order to regulate virulence factors production, biofilm formation, swarming motility, and sporulation. Therefore, QS helps bacteria invasion of the host when the number of bacterial cells is high, increasing the chances of successful infection, and thus the survival of bacterial pathogens [19]. Overall, resveratrol showed an antivirulence effect at concentration up to 64-fold below MIC values [11].

Resveratrol exhibited inhibitory activity on Listeria monocytogenes and Listeria innocua planktonic cells growth and biofilm formation at subinhibitory concentrations (sub-MIC) ranging from 50 to $100 \mu \mathrm{g} / \mathrm{mL}$. These activities were observed in lettuce model medium and chicken juice, but not in milk, which was probably because of the reduced bioavailability due to the hydrophobic interactions between resveratrol and milk proteins or fats. However, these results encouraged the potential use of resveratrol as a food preservative for certain types of food matrix [20].

In a recent study [21], resveratrol was identified as a promising agent against the Gram-negative anaerobic Porphyromonas gingivalis, which is a keystone in periodontitis: a chronic inflammatory oral disease leading to bone and connective tissue destruction [22]. Resveratrol displayed bacteriostatic and bactericidal effects on P. gingivalis ATCC 33277, ATCC 53978, and CS02 strains with a MIC value of $156 \mu \mathrm{g} / \mathrm{mL}$ and minimum bactericidal concentration (MBC) value of $312 \mu \mathrm{g} / \mathrm{mL}$, and on the CS01 strain with a MIC value of $78 \mu \mathrm{g} / \mathrm{mL}$ and MBC value of $156 \mu \mathrm{g} / \mathrm{mL}$. Furthermore, at sub-MIC concentration, resveratrol inhibited biofilm formation by reducing the gene expression of virulence factors, including the genes type II and IV fimA (encoding fimbriae that allow bacteria to bind to host cells, and cysteine protease $\operatorname{rgpA}$ ) and kgp genes (encoding gingipains, bacterial proteases involved in the cleavage of extracellular proteins, facilitating $P$. gingivalis biofilm growth) [21]. 
Resveratrol was used as pre-treatment at 1-100 $\mu \mathrm{M}$ concentration in Helycobacter pylori-infected cells, and it significantly inhibited IL-8 secretion by cells, suppressed reactive oxygen species (ROS) production, and remarkably blocked host cell morphological changes associated with cell dysregulation and pathogenesis [23]. Moreover, resveratrol inhibited the H. pylori growth with an MIC value ranging from 6.25 to $100 \mu \mathrm{g} / \mathrm{mL}$, depending on the tested strain [24-26]. Paulo et al. showed that resveratrol could work as an $H$. pylori urease inhibitor, preventing the production of a local alkaline environment from the conversion of urea into ammonia, which allows the microorganism to survive to the stomach acidic conditions [26].

In general, resveratrol was found to be less active against Gram-negative bacteria (MIC values > $200 \mathrm{mg} / \mathrm{mL}$ ) than against Gram-positive species. Efflux pump systems in Gram-negative species may be responsible for the decreasing susceptibility to resveratrol, as demonstrated by several experiments performed with mutants or in the presence of efflux pumps inhibitors. This observation suggested that the antibacterial activity of resveratrol could be partially due to the interaction with cytoplasmic or periplasmic targets in Gram-negative bacteria [11].

Furthermore, as Guo et al. [27] demonstrated, the antimicrobial activity of resveratrol may be related to the activation of the immune system response. Indeed, resveratrol and its dimethylated analogue pterostilbene (Figure 1) were found to activate the human cathelicidin antimicrobial peptide $(C A M P)$ in both myeloid and keratinocyte cells. The human CAMP is expressed in immune and epithelial cells and it is able to kill a wide spectrum of bacteria. The human CAMP gene expression is mediated by $1 \alpha, 25$-dihydroxyvitamin $\mathrm{D}_{3}\left(1 \alpha, 25(\mathrm{OH})_{2} \mathrm{D}_{3}\right)$, litocholic acid, butyrate, and vitamin $\mathrm{B} 3[27,28]$. When resveratrol and pterostilbene $(10 \mu \mathrm{M})$ were combined with $1 \alpha, 25(\mathrm{OH})_{2} \mathrm{D}_{3}(1 \mathrm{nM})$, they synergistically enhanced CAMP gene expression, representing a useful alternative to improve barrier defence and immune response against infections [27]. In another study [29] on the infection caused by the respiratory pathogen nontypeable Haemophilus influenzae (NTHi), leading to acute exacerbation of chronic obstructive pulmonary disease (AECOPD) [30], resveratrol resulted to be both an anti-inflammatory and antibacterial agent. Resveratrol displayed bacteriostatic effects on 14 genomically unrelated NTHi clinical strains at $175 \mu \mathrm{g} / \mathrm{mL}$, without inducing antibiotic resistance in in vitro studies. Nonetheless, when resveratrol was assessed as pre-treatment in airway epithelial cells at sub-MIC, the NTHi cells invasions were significantly reduced. Regarding the immunomodulatory properties, Euba et al. demonstrated that resveratrol was able to lower IL-8 and hBD2 (bacteria-induced human $\beta$-defensin-2) gene expression in NTHi-infected A459 airway epithelial cells. In in vivo experiments on pulmonary NTHi-infected mice, the oral administration of resveratrol $(150 \mathrm{mg} / \mathrm{kg})$ reduced the bacterial load and the lung-inflammatory markers such as KC and TNF- $\alpha$. To confirm these in vivo results in an alternative animal infection model, zebrafish was infected with NTHi and then treated by intraperitoneal administration of resveratrol $(0.1 \mathrm{mg} / \mathrm{g})$. The treated-zebrafish showed a significant decrease of $H$. influenzae c.f.u. (colony-forming units) and an increased survival with respect to those receiving perfusion solution-DMSO (1:1) [29]. Resveratrol was also studied as food preservative [31], evaluating the development of homologous (adaptation to the same products) and cross-resistance to different agents or stress conditions such as heat and acidic conditions, after exposure and adaptation of the foodborne pathogens L. monocytogenes and S. aureus to sub-MIC of resveratrol (MIC value $200 \mu \mathrm{g} / \mathrm{mL}$ and MBC value $400 \mu \mathrm{g} / \mathrm{mL}$ for both bacteria). Resveratrol adaptation of both S. aureus and L. monocytogenes did not result to induce homologous or cross-resistance to benzalkonium chloride and other tested antibiotics. However, an increase of MIC value of benzalkonium chloride from 2 to $4 \mu \mathrm{g} / \mathrm{mL}$ was observed in L. monocytogenes after eight sequential exposures to resveratrol $(0.5 \times \mathrm{MIC})$, which is likely due to the antioxidant properties of the polyphenol partially interfering with the oxidative stress induced by benzalkonium chloride. Studies were also performed to evaluate the tolerance to both heat and acidic conditions, which are treatments commonly applied in the food industry to eliminate microorganisms such as S. aureus and L. monocytogenes. An increment of survival rate of both studied microorganisms was observed upon adaptation to resveratrol and exposure to 
$55{ }^{\circ} \mathrm{C}$ and low $\mathrm{pH}(2.4)$, suggesting the role of resveratrol in the modification of cellular structures or protein synthesis leading to increased stress tolerance [31].

\subsection{Natural and Synthetic Resveratrol Analogues}

Beyond resveratrol, in nature, there are several monomeric stilbenoids, differing in the position and number of hydroxy or methoxy groups at the two aromatic rings of the 1,2-diphenylethylene scaffold (Figure 1) [32]. The antistaphylococcal activity of a series of plant-derived resveratrol analogues was evaluated in in vitro studies against six ATCC (American Typical Culture Collection) strains and two clinical isolates of S. aureus (KI1 and KI2) [33] (Figure 1). Pterostilbene resulted to be the strongest growth inhibitor against all S. aureus strains, with an MIC value of $32 \mu \mathrm{g} / \mathrm{mL}$, followed by piceatannol (MICs $=64-256 \mu \mathrm{g} / \mathrm{mL}$ ), and pinostilbene $(\mathrm{MIC}=128 \mu \mathrm{g} / \mathrm{mL}$ ) (Figure 1, Table 1). Piceatannol was the most active compound. This finding confirmed previous evidence that the increasing number of hydroxy groups on phenolic compounds is associated with increasing toxicity to microorganisms [34]. However, since oxyresveratrol was found to be far less active than piceatannol, the position of the hydroxy groups was demonstrated to play another key role in the biological activity, according to previous observations [35]. Moreover, the number and the position of hydroxyl groups on ring B seemed to be more relevant for the inhibitory activity than the ones on ring A. In particular, ortho-dihydroxy groups on ring B significantly increased the antistaphylococcal effect. Conversely, on ring A, methoxy groups enhanced the antibacterial activity on S. aureus (3'-hydroxystilbene, pinostilbene, and pterostilbene), which decreased in the correspondent analogues with methoxy groups on the ring B (isorhapontigenin and rhapontigenin) [33]. This observation was further confirmed by a more recent study reporting the testing of a collection of resveratrol analogues and dimers against a panel of bacteria [36]. The permethylated and peracetylated monomers (i.e., trimethylresveratrol and triacetylresveratrol) were completely inactive, whereas pterostilbene displayed the strongest growth-inhibitor activity against $S$. aureus (MIC value $=4 \mu \mathrm{g} / \mathrm{mL}$ ), along with its isomer 3,4'-dimethoxyresveratrol (MIC value $=64 \mu \mathrm{g} / \mathrm{mL}$ ) (Figure 1, Table 2). Pterostilbene, bearing two methoxy groups on ring $A$ and one hydroxyl group on ring $B$, resulted to be more active than the $3,4^{\prime}$-dimethoxy isomer. The same difference in the antibacterial activity between the two compounds was observed also against other Gram-positive bacteria, such as L. monocytogenes Scott A and E. faecalis DSM 20478, whereas 3,4'-dimethoxyreveratrol was more potent against E. faecium DSM 20477 and B. cereus DSM 9378. On the other hand, pinostilbene and desoxyrhapontigenin were the only monomers displaying a moderate activity against Gram-negative bacteria [36].

Table 1. In vitro growth-inhibitory effect of stilbenoids against S. aureus from Zakova et al. (2018) [33].

\begin{tabular}{|c|c|c|c|c|c|c|c|c|}
\hline \multirow[b]{2}{*}{ Compound } & \multicolumn{8}{|c|}{ Strain Tested/MIC $(\mu \mathrm{g} / \mathrm{mL})$} \\
\hline & $\begin{array}{l}\text { ATCC } \\
43300\end{array}$ & $\begin{array}{l}\text { ATCC } \\
25923\end{array}$ & $\begin{array}{c}\text { ATCC } \\
\text { BAA 976 }\end{array}$ & $\begin{array}{l}\text { ATCC } \\
29213\end{array}$ & $\begin{array}{l}\text { ATCC } \\
33591\end{array}$ & $\begin{array}{l}\text { ATCC } \\
33592\end{array}$ & KI1 & KI2 \\
\hline 3'-Hydroxypterostilbene & 256 & 128 & 256 & 128 & 128 & 128 & 256 & 256 \\
\hline Isorhapontigenin & 128 & 256 & 256 & 256 & 256 & 256 & 256 & 256 \\
\hline Oxyresveratrol & 256 & 256 & 256 & 256 & 256 & 256 & 256 & 256 \\
\hline Piceatannol & 64 & 64 & 64 & 64 & 64 & 64 & 64 & 256 \\
\hline Pinostilbene & 128 & 128 & 128 & 128 & 128 & 128 & 128 & 128 \\
\hline Pterostilbene & 32 & 32 & 32 & 32 & 64 & 32 & 32 & 64 \\
\hline Resveratrol & $>512$ & 256 & $>512$ & $>512$ & $>512$ & 256 & $>512$ & $>512$ \\
\hline Rhapontigenin & 256 & 256 & 256 & 256 & 256 & 128 & 256 & 256 \\
\hline Oxacillin * & 16 & 0.125 & 8 & 0.125 & 128 & 64 & 1 & 16 \\
\hline
\end{tabular}

MIC: minimum inhibitory concentration; ATCC: American type culture collection; KI: clinical isolates. ${ }^{*}$ Represents reference control. 
Table 2. MIC and minimum bactericidal concentration (MBC) values (in brackets) of stilbenoid monomers from Mattio et al. (2019) [36].

\begin{tabular}{|c|c|c|c|c|c|c|}
\hline \multirow{2}{*}{ Compound } & \multicolumn{6}{|c|}{ MIC (MBC) $\mu \mathrm{g} / \mathrm{mL}$} \\
\hline & $\begin{array}{c}\text { S. aureus ATCC } \\
25923\end{array}$ & $\begin{array}{c}\text { P. aeruginosa } \\
\text { ATCC } 27853\end{array}$ & $\begin{array}{l}\text { L. monocytogenes } \\
\text { Scott A }\end{array}$ & $\begin{array}{l}\text { E. faecium } \\
\text { DSM } 20477\end{array}$ & $\begin{array}{l}\text { E. faecalis } \\
\text { DSM } 20478\end{array}$ & $\begin{array}{c}\text { B. cereus } \\
\text { DSM } 9378\end{array}$ \\
\hline Resveratrol & $512(>512)$ & $>512(>512)$ & - & - & - & - \\
\hline Pterostilbene & $4(128)$ & $512(512)$ & $64(128)$ & $32(512)$ & $32(128)$ & $16(512)$ \\
\hline Piceatannol & $>512(>512)$ & $128(>512)$ & - & - & - & - \\
\hline 3'-Hydroxy-pter. & $128(512)$ & $128(>512)$ & - & - & - & - \\
\hline Trimethoxy-res. & $>512(>512)$ & $>512(>512)$ & - & - & - & - \\
\hline Triacetoxy-res. & $>512(>512)$ & $>512(>512)$ & - & - & - & - \\
\hline 3,4'-Dimethoxy-res. & $64(512)$ & $128(256)$ & $256(512)$ & $4(512)$ & $128(512)$ & $8(>512)$ \\
\hline Desoxy-rhapontigenin & $256(>512)$ & $64(>512)$ & - & - & - & - \\
\hline Pinostilbene & $512(>512)$ & $64(>512)$ & - & - & - & - \\
\hline
\end{tabular}

In 2019, Singh et al. [37] investigated the antibacterial activity of some natural stilbenoids and their synthetic analogues (Figure 1) against a panel of Gram-negative and Gram-positive bacteria. In the case of Gram-positive bacteria, 4'-bromo resveratrol, pinosylvin, pinostilbene hydrate, pterostilbene, and the dimer of 4,4'-dihydroxystilbene (Di-DHS) was shown to be more effective than resveratrol. In particular, pinosylvin and pterostilbene exhibited an MIC value of $25 \mu \mathrm{g} / \mathrm{mL}$ and Di-DHS exhibited an MIC value of $10 \mu \mathrm{g} / \mathrm{mL}$ against $S$. aureus. The antibacterial activity of $4^{\prime}$-bromo resveratrol and Di-DHS was directly correlated to oxidative stress, DNA cleavage, membrane damage, and physical perturbation, revealed by SEM (scanning electron microscope) analysis on S. aureus. In the case of Gram-negative bacteria, resveratrol resulted to be active against Proteus vulgaris MTCC 426 and Salmonella typhimurium MTCC 660 (inhibition: approximately $45 \%$ in both cases). All the other analogues were less potent than resveratrol, except for 4'-bromo resveratrol and pinosylvin, which showed higher inhibition than resveratrol against the two aforementioned Gram-negative bacteria and Escherichia coli BW25113 (inhibition >80\%), whereas pinostilbene hydrate showed activity comparable to resveratrol. Experiments on $\Delta$ tolC E. coli (lacking efflux pumps) demonstrated that the poor activity on Gram-negative strains was due to the presence of efflux pump systems. Notably, all compounds were significantly more active against $\Delta$ tolC than against wild-type bacteria, except for 4,4'-dihydrostilbene (DHS), triacetylresveratrol, and trimethylresveratrol, which were inactive against all strains. Only $4^{\prime}$-bromo resveratrol and pinosylvin showed similar activity on $\Delta$ tolC and wild-type bacteria, presumably because they were poor substrates for the efflux pumps or able to act before being effluxed out. This study confirmed that hydroxy groups are fundamental for antibacterial activity. In fact, triacetylresveratrol and trimethoxyresveratrol were totally inactive. However, increasing the number of hydroxy groups did not increase the potency of piceatannol and oxyresveratrol, which conversely were less active than resveratrol. Furthermore, even if DHS and piceatannol did not show any relevant antibacterial activity, the most active compounds in this study (resveratrol, 4'-bromo resveratrol, pinostilbene, pterostilbene, Di-DHS) bear a substituent at the para-position, except for pinosylvin [37].

Pterostilbene was studied as an anti-biofilm agent against various opportunistic pathogens [38]. It displayed inhibitory activity on planktonic cells growth with an $\mathrm{MIC}_{50}$ (lowest concentration that did not allow visible growth of more than $50 \%$ ) values of 18.60 and $25 \mu \mathrm{g} / \mathrm{mL}$ on S. epidermidis DMB 3179, P. aeruginosa NRRL B-59189, and E. coli DBM3125, respectively. In particular, pterostilbene showed a significant reduction of biofilm formation on E. coli ( $\mathrm{MAIC}_{50}$, minimum adhesion inhibition concentration, $=40 \mu \mathrm{g} / \mathrm{mL}$ ) and $S$. epidermidis $\left(\mathrm{MAIC}_{50}=50 \mu \mathrm{g} / \mathrm{mL}\right.$ ), but it did not affect P. aeruginosa $\left(\mathrm{MAIC}_{50}>170 \mu \mathrm{g} / \mathrm{mL}\right)$. However, pterostilbene was more effective in the pre-formed biofilm eradication of S. epidermidis, with an $\mathrm{MBEC}_{50}$ (minimum biofilm eradication concentration) of $25 \mu \mathrm{g} / \mathrm{mL}$, than in the inhibition of biofilm formation [38].

Famuyiwa et al. [39] investigated the bioactivity of compounds extracted from the yellow inter-bulb of Scilla nervosa (Burch.) Jessop (Hyacinthaceae family), which is an important plant used in traditional medicine in Southern Africa to treat infections, inflammations, pains, constipation, and infertility [40]. Among the isolated compounds, only the stilbenoid isorhapontigenin (Figure 1) was found to display antibacterial activity, showing an MIC value of $19.53 \mu \mathrm{g} / \mathrm{mL}$, but a high MBC value $(312.50 \mu \mathrm{g} / \mathrm{mL})$ against Neisseria gonorrhoeae (ATCC 49226) [39]. 
Rhapontigenin and desoxyrhapontigenin (Figure 1) extracted from the rhizomes of Rheum tanguticum Maxim. Ex Balf. (Polygonaceae family) displayed moderate in vitro antibacterial activity against various phytopathogens (Table 3) [41].

Table 3. MIC of stilbenoids against phytopathogenic microorganisms from Pham et al. (2017) [41].

\begin{tabular}{ccccccc}
\hline \multirow{2}{*}{ Compound } & \multicolumn{7}{c}{ MIC $(\mu \mathrm{g} / \mathrm{mL})$} \\
\cline { 2 - 7 } & $\begin{array}{c}\text { Acidovorax } \\
\text { avenae subsp. } \\
\text { cattlyae }\end{array}$ & $\begin{array}{c}\text { Agrobacterium } \\
\text { tumefaciens }\end{array}$ & $\begin{array}{c}\text { Burkholderia } \\
\text { glumae }\end{array}$ & $\begin{array}{c}\text { Clavibacter } \\
\text { michiganensis subsp. } \\
\text { michiganensis }\end{array}$ & $\begin{array}{c}\text { Pectobacterium } \\
\text { carotovora subsp. } \\
\text { carotovora }\end{array}$ & $\begin{array}{c}\text { Pseudomonas } \\
\text { syringae pv. } \\
\text { actinidiae KW11 }\end{array}$ \\
\hline Rhapontigenin & 150 & 150 & 75 & 150 & 300 & - \\
Desoxyrhapontigenin & 38 & 75 & 38 & 75 & - & 38 \\
\hline
\end{tabular}

Pinosylvin (PS), pinosylvin monomethyl ether (PSMME), and dihydropinosylvin monomethyl ether (DHPSMME) (Figure 1), which were extracted from the knotwood and barks of different Pinus species, were tested against a panel of Gram-positive and Gram-negative bacteria (Table 4). DHPSMME showed the lowest activity, which was likely due to the absence of the double bond, which should mediate the electron transfer capability between the aromatic rings. Moreover, the two hydroxy groups at the meta position seemed to play a key role in the antimicrobial activity [42].

Table 4. Antibacterial activity of pinosylvins from Välimaa et al. (2007) [42]. DHPSMME: dihydropinosylvin monomethyl ether, PS: pinosylvin, PSMME: pinosylvin monomethyl ether.

\begin{tabular}{cccccccc}
\hline \multirow{2}{*}{ Compound } & \multicolumn{5}{c}{ Inhibitory Effect (Percentage of Inhibition, Mean \pm sd) } \\
\cline { 2 - 8 } & E. coli & S. infantis & P. fluorescens & B. cereus & S. aureus & L. monocytogenes & L. plantarum \\
\hline PS & $18 \pm 2$ & $14 \pm 2$ & $22 \pm 6$ & $82 \pm 3$ & $76 \pm 4$ & $64 \pm 12$ & $1 \pm 1$ \\
PSMME & $54 \pm 8$ & $42 \pm 20$ & $50 \pm 15$ & $101 \pm 6$ & $76 \pm 2$ & $62 \pm 15$ & $0 \pm 0$ \\
DHPSMME & $15 \pm 2$ & $14 \pm 8$ & $7 \pm 3$ & $74 \pm 6$ & $30 \pm 9$ & $55 \pm 16$ & $4 \pm 5$ \\
\hline
\end{tabular}

Studying secondary metabolites produced by $B$. cereus symbiotically associated with the entomopathogenic nematode (EPN) Rhabditis (Oscheius) sp. (a biocontrol agent against insect pests), Kumar et al. [43] isolated 3,5-dihydroxy-4-ethyl-trans-stilbene (ES) along with 3,5-dihydroxy4-isopropyl-trans-stilbene (Figure 1). Confirming previous studies [44], ES was active only against Gram-positive bacteria, with MICs = 8-16 $\mathrm{gg} / \mathrm{mL}$ on S. aureus MTCC 902 and B. subtilis MTCC 2756, whereas 3,5-dihydroxy-4-isopropyl-trans-stilbene inhibited also the growth of the Gram-negative E. coli MTCC 2622 (MIC = $8 \mu \mathrm{g} / \mathrm{mL}$ ) [45]. In another study [46], 3,5-dihydroxy-4-isopropyl-trans-stilbene was isolated along with its epoxide (Figure 1), which was produced by Photorhabdus luminescens, an entomopathogenic gammaproteobacterium. Both compounds showed a good antibacterial activity against B. subtilis (NCIB3610) and E. coli (Nissle 1917) (MIC in the range 3-25 $\mu \mathrm{g} / \mathrm{mL}$ ) [46].

Piceatannol was found to display anti-biofilm activity against $S$. mutans at low micromolar concentrations $\left(\mathrm{IC}_{50}=52 \mu \mathrm{M}\right)$ through the inhibition of glucosyltransferases (Gtfs) [47]. S. mutans synthesises high-molecular weight glucosyl polymers by Gtfs to adhere to the tooth surfaces and to trap other oral bacteria and components contributing to the cariogenic environment development [48]. The compound did not inhibit the growth of commensal species such as S. sanguinis and S. gordonii, resulting in being highly selective for $S$. mutans biofilm. Moreover, piceatannol inhibited S. mutans colonisation in in vivo drosophila and rat models [47].

Sheng et al. studied the QS-inhibiting effects of 10 stilbenoids against Chromobacterium violaceum CV026 and P. aeruginosa PAO1, performing SAR studies [49]. Resveratrol, oxyresveratrol, and piceatannol displayed anti-QS activity against C. violaceum that was used as an indicator strain, since it produces violacein as a QS factor, creating a purple background. The presence of a white or cream halo around the well against the coloured background indicates QS inhibition. When the compounds lacking double bonds (phenantrenes or dihydrostilbenes) were tested, any QS inhibition was observed. Furthermore, pterostilbene was found to be inactive, highlighting the importance of hydroxy groups at the $3^{\prime}$ - and $5^{\prime}$-position for the activity. Given that the active compounds were tested 
on P. aeruginosa. Resveratrol, oxyresveratrol, and piceatannol decreased the production of pyocyanin, which is a virulence factor controlled by QS at sub-MIC concentrations $(400 \mu \mathrm{M})$. Moreover, the same three compounds significantly altered P. aeruginosa swarming motility at $100 \mu \mathrm{M}$ dose [49].

Studying the extracts of Ficus polita, an edible plant from the family of Moraceae, largely used to treat infectious diseases, Kuete et al. identified (E)-3,5,4'-trihydroxy-stilbene-3,5-O- $\beta$ - $D$-diglucopyranoside (Figure 1), which was tested against P. smartii ATCC29916, P. aeruginosa PA01, K. pneumoniae ATCC11296, S. aureus ATCC25922, S. typhi ATCC6539, E. coli ATCC8739, and E.coli AG100, displaying a moderate inhibitory activity (MIC in the range $64-256 \mu \mathrm{g} / \mathrm{mL}$ ) [50].

Cicerfuran (Figure 2, compound 3e), a 2-arylbenzofuran belonging to the stilbene family, was first isolated from the roots of Cicer bijugum, which is a wild species of chickpea. Since it was reported to be produced as plant defence against Fusarium oxysporum f.sp. ciceri, Aslam et al. carried out the synthesis of cicerfuran along with other five 2-arylbenzofuran analogues and nine structural related stilbenes to investigate the antimicrobial activity and to perform SAR studies [51]. The synthesised compounds were tested against B. subtilis (IMI347329) and P. syringae (ATCC19310) (Table 5). Only compounds $\mathbf{1 b}, \mathbf{2 b}, \mathbf{2 d}, \mathbf{2 e}$, and cicerfuran $\mathbf{3 e}$ (Figure 2) showed antibacterial activity with MIC values ranging from 25 to $100 \mu \mathrm{g} / \mathrm{mL}$, highlighting the importance of the hydroxy function in the structure. Moreover, compounds $\mathbf{2} \mathbf{d}$ and $\mathbf{2 e}$, bearing a methylenedioxy group as common structural feature, exerted similar activity, inhibiting the growth of both bacterial species. Conversely, compound $\mathbf{1 b}$ was active only against $P$. syringae [52].<smiles>[R]c1ccc(/C=C/c2ccccc2)c([R])c1</smiles>

1a $\mathrm{R}_{1}=\mathrm{R}_{2}=\mathrm{H}$

1b $\mathrm{R}_{1}=\mathrm{OH} ; \mathrm{R}_{2}=\mathrm{OH}$

1c $\mathrm{R}_{1}=\mathrm{H} ; \mathrm{R}_{2}=\mathrm{OCH}_{3}$

1d $\mathrm{R}_{1}=\mathrm{R}_{2}=\mathrm{OCH}_{3}$

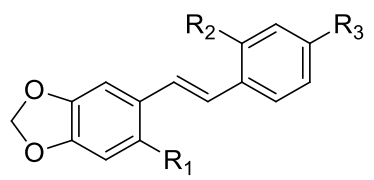

2a $R_{1}=R_{2}=R_{3}=H$

2b $\mathrm{R}_{1}=\mathrm{H} ; \mathrm{R}_{2}=\mathrm{R}_{3}=\mathrm{OH}$

2c $\mathrm{R}_{1}=\mathrm{R}_{2}=\mathrm{H} ; \mathrm{R}=\mathrm{OCH}_{3}$

2d R $\mathrm{R}_{1}=\mathrm{CH}_{3} ; \mathrm{R}_{2}=\mathrm{OH} ; \mathrm{R}_{3}=\mathrm{H}$

2e $\mathrm{R}_{1}=\mathrm{OCH}_{3} ; \mathrm{R}_{2}=\mathrm{OH} ; \mathrm{R}_{3}=\mathrm{H}$

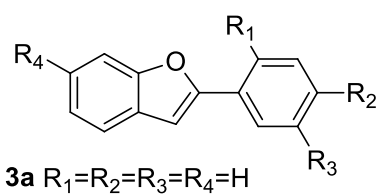

3b $\mathrm{R}_{1}=\mathrm{R}_{4}=\mathrm{H} ; \mathrm{R}_{2}=\mathrm{R}_{3}=-\mathrm{OCH}_{2} \mathrm{O}-$

3c $\mathrm{R}_{1}=\mathrm{OCH}_{3} ; \mathrm{R}_{4}=\mathrm{H} ; \mathrm{R}_{2}=\mathrm{R}_{3}=-\mathrm{OCH}_{2} \mathrm{O}$

3d $\mathrm{R}_{1}=\mathrm{CH}_{3} ; \mathrm{R}_{4}=\mathrm{H} ; \mathrm{R}_{2}=\mathrm{R}_{3}=-\mathrm{OCH}_{2} \mathrm{O}-$

3e $\mathrm{R}_{1}=\mathrm{OCH}_{3} ; \mathrm{R}_{4}=\mathrm{OH} ; \mathrm{R}_{2}=\mathrm{R}_{3}=-\mathrm{OCH}_{2} \mathrm{O}$

3f $\mathrm{R}_{1}=\mathrm{R}_{4}=\mathrm{OCH}_{3} ; \mathrm{R}_{2}=\mathrm{R}_{3}=-\mathrm{OCH}_{2} \mathrm{O}-$

Figure 2. Structures of cicerfuran and synthetic analogues from Aslam et al. (2009) [52].

Table 5. MIC values of cicerfuran and its analogues from Aslam et al. (2009) [52].

\begin{tabular}{ccc}
\hline \multirow{2}{*}{ Compound } & \multicolumn{2}{c}{ MIC $(\mu \mathrm{g} / \mathrm{mL})$} \\
\cline { 2 - 3 } & B. subtilis & P. syringae \\
\hline $1 \mathrm{a}$ & $>400$ & $>400$ \\
$1 \mathrm{~b}$ & $>400$ & 25 \\
$1 \mathrm{c}$ & $>400$ & $>400$ \\
$1 \mathrm{~d}$ & $>400$ & $>400$ \\
$2 \mathrm{a}$ & $>400$ & $>400$ \\
$2 \mathrm{~b}$ & $* \mathrm{nt}$ & $* \mathrm{nt}$ \\
$2 \mathrm{c}$ & $>400$ & $>400$ \\
$2 \mathrm{~d}$ & 25 & 25 \\
$2 \mathrm{e}$ & 25 & 50 \\
$3 \mathrm{a}$ & $>400$ & $>400$ \\
$3 \mathrm{~b}$ & $>400$ & $>400$ \\
$3 \mathrm{c}$ & $>400$ & $>400$ \\
$3 \mathrm{~d}$ & $>400$ & $>400$ \\
$3 \mathrm{e}$ & 25 & 25 \\
$3 \mathrm{f}$ & $>400$ & $>400$ \\
$* *$ CAF & 0.78 & 0.78
\end{tabular}

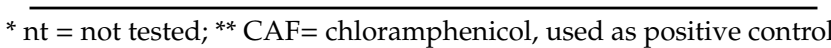


Resveratrol was found to directly interact with myeloperoxidase (MPO) [53], which is a haem enzyme released by activated phagocytes during inflammation response. It catalyses the conversion of hydrogen peroxide into hypochlorous acid $(\mathrm{HOCl})$ and hypobromous acid $(\mathrm{HOBr})$, in the presence of physiological concentration of chloride and bromide anions, respectively [54]. The resulting hypohalous acids can act as antibacterial agents [55] and play a key role in the immune response, besides interacting with biological molecules, such as nucleic acids, proteins, and lipids, thanks to their antioxidant and electrophilic properties [56,57]. Furthermore, resveratrol was shown to significantly reduce the production of $\mathrm{HOCl}$ and nitric oxide $(\mathrm{NO})$ produced by stimulated human neutrophils in a dose-dependent manner, acting on MPO [58]. Therefore, Li et al. [59] investigated resveratrol halogenated products, upon reaction with $\mathrm{HOCl}$ and $\mathrm{HOBr}$, and their biological activities (Figure 3). The halogenated resveratrol derivatives were tested against S. aureus ATCC 25923 and E. coli ATCC 25922. Interestingly, the halogenation occurred only at the aromatic ring A, bearing two nucleophilic hydroxy groups, thus facilitating the electrophilic aromatic substitution. Resveratrol and its chloro-derivative $4 \mathbf{d}$ were the most active against the Gram-positive S. aureus, but only compound $4 \mathbf{d}$ maintained a good potency also against the Gram-negative E. coli, against which resveratrol resulted to be less active than all the halogenated derivatives synthesised (Table 6) [59].
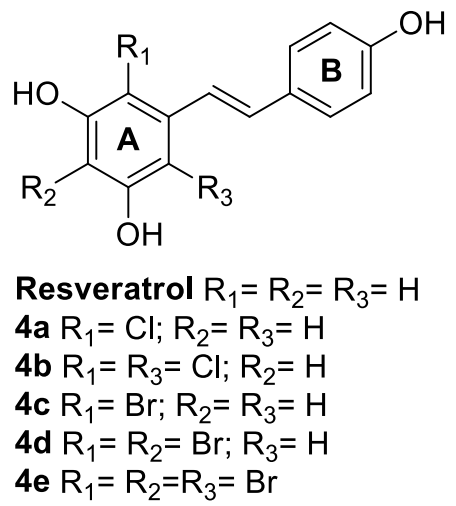

Figure 3. Structures of halogenated resveratrol derivatives from Li et al. (2012) [59].

Table 6. MIC of some halogenated resveratrol derivatives from Li et al. (2012) [59].

\begin{tabular}{ccc}
\hline \multirow{2}{*}{ Compound } & \multicolumn{2}{c}{ MIC $(\mu \mathrm{g} / \mathrm{mL})$} \\
\cline { 2 - 3 } & $\begin{array}{c}\text { E. coli } \\
\text { ATCC 25922 }\end{array}$ & $\begin{array}{c}\text { S. aureus } \\
\text { ATCC 25923 }\end{array}$ \\
\hline Resveratrol & 250 & 3.90 \\
4a & 31.3 & 31.3 \\
4b & 125 & 62.5 \\
4c & 62.5 & 31.3 \\
4d & 15.6 & 3.90 \\
4e & 31.3 & 7.81 \\
* Levofloxacin & 0.156 & 0.156 \\
\hline
\end{tabular}

${ }^{*}$ Levofloxacin was used as positive control.

To improve the antimicrobial effects of natural stilbenoids, several research groups focused on the synthesis of new derivatives containing the stilbene backbone. Many synthetic pathways to obtain modified stilbenoids have been investigated, such as aldol-type condensations, Perkin reactions, McMurry reactions, and recently the metal catalysed Mizoroki-Heck reactions [60,61].

In 2011, by Mizoroki-Heck reaction, Albert et al. [62] prepared 25 compounds divided into three groups: 4-hydroxy stilbenes (e.g., compound 5), 3-hydroxystilbenes (e.g., compound 6) and 2-hydroxy stilbenes (e.g., compound 7) (Figure 4). The compounds were tested in an agar diffusion assay for their antibacterial and antifungal activities. In particular, the stilbenoids reported in Figure 4 were the 
most active among the synthesised compounds, demonstrating significant growth inhibition of the Gram-positive Bacillus subtilis and Bacillus brevis, and the actinobacteria Micrococcus luteus (inhibition zone diameters ranging from 8 to $20 \mathrm{~mm}$ ), even if less active than commercial antibiotics (streptomycin and tetracycline with inhibition zone diameters of 7-22 mm). All 25 molecules were inactive against the Gram-negative bacterium Enterobacter dissolvens. The data suggested that all stilbene derivatives needed two hydroxyl groups at the $2^{\prime}$ and $5^{\prime}$ positions on ring B to display antibacterial activity, if they were not mono-hydroxy substituted on ring A. Moreover, fluorine substituents enhanced the antibacterial effect, providing higher permeability of the compounds into the membrane [62].<smiles>Oc1ccc(/C=C/c2cc(O)ccc2O)cc1</smiles>

5<smiles>[R]c1cc(/C=C/c2cc(O)c([R3])c([R2])c2[R7])c([R])c([R])c1[R]</smiles>
6a, $\mathrm{R}_{1}{ }^{\prime}=\mathrm{R}_{2}{ }^{\prime}=\mathrm{R}_{3}{ }^{\prime}=\mathrm{H} ; \mathrm{R}_{1}=\mathrm{R}_{4}=\mathrm{OH} ; \mathrm{R}_{2}=\mathrm{R}_{3}=\mathrm{H}$
6b, $R_{1}^{\prime}=F ; R_{2}^{\prime}=H ; R_{3}^{\prime}=O M e ; R_{1}=R_{4}=O H ; R_{2}=R_{3}=H$
6c, $\mathrm{R}_{1}{ }^{\prime}=\mathrm{R}_{2}{ }^{\prime}=\mathrm{H} ; \mathrm{R}_{3}{ }^{\prime}=\mathrm{OH} ; \mathrm{R}_{1}=\mathrm{R}_{4}=\mathrm{OH} ; \mathrm{R}_{2}=\mathrm{R}_{3}=\mathrm{H}$
6d, $R_{1}^{\prime}=R_{2}^{\prime}=H ; R_{3}^{\prime}=O M e ; R_{1}=R_{4}=O H ; R_{2}=R_{3}=H$<smiles>Oc1ccc(O)c(/C=C/c2ccccc2O)c1</smiles>

7

Figure 4. Synthetic stilbene derivatives from Albert et al. (2011) [62].

\subsection{Prenylated Stilbenoids}

Prenylated stilbenoids are mainly isolated from the Leguminosae family, e.g., soybean, peanuts, mung bean, and their production can be stimulated by fungal elicitation. In particular, a prenyltransferase is responsible for attaching a prenyl-moiety to the phenol ring, and in the case of peanut stilbenoids, the prenylation usually occurs at the para position [63]. The prenyl-chain (3,3-dimethylallyl or 3-methyl-but-1-enyl substituent) may undergo further enzymatic cyclisation with an ortho-phenolic hydroxy group leading to five- or six-membered rings, which are furan and pyran derivatives respectively [64]. Since the prenylation of phenolic compounds increases in response to microbial attack in legume seeds, prenylated phenolic compounds are believed to have better antimicrobial properties than their non-prenylated precursors [65], and generally, this hypothesis has been confirmed [66,67]. This observation was traditionally explained as an effect of the enhanced hydrophobicity, which improves the affinity to biological membranes and the interaction with target proteins [64]. However, the specific position and the configuration of the prenyl chain seem to influence the bioactivity more than the hydrophobic effect [66]. De Bruijin et al. [68] isolated a series of prenylated stilbenes from an extract of Rhizopus-elicited peanut seedlings (Arachis hypogaea) and 
tested their antibacterial activity against $S$. aureus MRSA strain (18HN, spa type t034), using the corresponding non-prenylated precursors piceatannol, resveratrol, and pinosylvin as references to perform SAR analysis (Figure 5, Table 7). Chiricanine A was the most active molecule among the tested compounds. All the prenylated derivatives were more potent than their precursors, and within the tested compounds, the pyran ring enhanced the activity more than the prenyl chain. Nonetheless, the number of hydrogen bonds resulted negatively correlated with the anti-MRSA activity [68]. However, there was no correlation between the hydrophobicity and activity among the prenylated compounds, according to previous findings [67].<smiles>CC(C)/C=C/c1c(O)cc(/C=C/c2ccc(O)c(O)c2)cc1O</smiles><smiles>CC(C)=CCc1c(O)cc(/C=C/c2ccc(O)cc2)cc1O</smiles><smiles>CC(C)/C=C/c1c(O)cc(/C=C/c2ccc(O)cc2)cc1O</smiles><smiles>CC1(C)C=Cc2c(O)cc(/C=C/c3ccc(O)c(O)c3)cc2O1</smiles><smiles>CC1(C)C=Cc2c(O)cc(/C=C/c3ccc(O)cc3)cc2O1</smiles><smiles>CC(C)=CCc1c(O)cc(/C=C/c2ccccc2)cc1O</smiles><smiles>COc1cc(/C=C/c2ccccc2)cc(O)c1CC=C(C)C</smiles>

Figure 5. Structures of prenylated stilbenoids from de Bruijn et al. (2018) [68] and Wu et al. (2020) [69].

Table 7. Structural characteristics and antibacterial activity of the prenylated compounds from de Bruijn et al. (2018) [68].

\begin{tabular}{ccccc}
\hline Compound & Precursor & $\begin{array}{c}\mathbf{n}^{\circ} \text { H-Bond } \\
\text { Donors }\end{array}$ & Log $_{7.2}$ & MIC $(\mu \mathrm{g} / \mathbf{m L})$ \\
\hline Piceatannol & n.a. & n.a. & 3.06 & $>200$ \\
Resveratrol & n.a. & n.a. & 3.38 & $>200$ \\
Pinosylvin & n.a. & n.a. & 3.69 & $\leq 100$ \\
Arachidin-1 & Piceatannol & 4 & 4.93 & $>50$ \\
Arachidin-2 & Resveratrol & 3 & 5.10 & $>50$ \\
Arachidin-3 & Resveratrol & 3 & 5.23 & $>50$ \\
Arachidin-6 & Piceatannol & 3 & 4.27 & $50-75$ \\
Arahypin-5 & Resveratrol & 2 & 4.58 & $25-50$ \\
Chiricanine A & Pinostilbene & 2 & 5.40 & 12.5 \\
\hline
\end{tabular}

n.a., not applicable. $\log \mathrm{D}_{7.2}$ calculated octanol-water partitioning coefficient at pH 7.2.

Wu et al. [69] evaluated the antibacterial activity of longistylin A (LLA) (Figure 5), an abundant prenylated stilbene isolated from the leaves of Cajanus cajan (L.) Millsp., which is commonly known as pigeon pea. The molecule was found to be inactive against $E$. coli, but it exerted significant antimicrobial activity against MRSA strains, displaying higher bactericidal activity (MBC) than 
vancomycin (Table 8). LLA antibacterial activity seemed related to a membrane potential dissipation and enhanced permeability, which induced cell lysis. Moreover, LLA was found to be effective as a topical agent to treat MRSA-infected wounds in mice by preventing further pathogens proliferation and reducing inflammation derived from the infection [69].

Table 8. Antibacterial activity of longistylin A (LLA) compared with vancomycin (VAN) from Wu et al. (2020) [69].

\begin{tabular}{cccccc}
\hline \multicolumn{7}{c}{ MIC $[\mathrm{MBC}](\mu \mathrm{g} / \mathrm{mL})$} \\
\hline \multirow{2}{*}{ Compound } & MRSA JCSC & MRSA JCSC & S. aureus & B. cereus & E. coli ATCC \\
& $\mathbf{4 7 4 4}$ & $\mathbf{4 4 6 9}$ & CMCC 26003 & CMCC 63302 & $\mathbf{8 7 3 9}$ \\
\hline LLA & $1.56[1.56]$ & $1.56[1.56]$ & $1.56[1.56]$ & $25[50]$ & $>100[>100]$ \\
VAN & $0.78[3.12]$ & $0.78[1.56]$ & $1.56[3.12]$ & $50[100]$ & $50[100]$ \\
\hline
\end{tabular}

MIC, minimum inhibitory concentration; in square brackets MBC, minimum bactericidal concentration; MRSA, methicillin-resistant $S$. aureus. ${ }^{a}$ VAN (vancomycin), used as positive control.

A series of chromene and chromane stilbenoids was isolated from the leaves of Hymenocardia acida Tul. (Phyllanthaceae family), which is a small African tree used in traditional medicine to treat malaria, sickle-cell disease, cancer, and hypertension (Figure 6). The isolated stilbenoids were tested against MRSA-108 S. aureus, and they were found to display a moderate activity against the tested drug-resistant strain, showing hymenocardichromanic acid to be the most active compound $(\mathrm{MIC}=8 \mu \mathrm{g} / \mathrm{mL})($ Table 9$)[70]$.<smiles>[R]c1c(O)c2c(c([R])c1/C=C/c1ccccc1)O[C@]([R3])(C)C=C2</smiles>

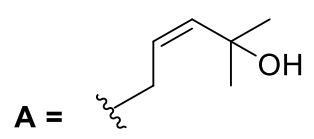<smiles>C=CCCCC(=O)C(=C)C</smiles><smiles>[B]=CCCC(O)C(=C)C</smiles>

Hymenocardichromene A $\mathrm{R}_{1}=\mathrm{H} ; \mathrm{R}_{2}=$ prenyl; $\mathrm{R}_{3}=\mathrm{Me}$ Hymenocardichromene $B \quad \mathrm{R}_{1}=\mathrm{COOH} ; \mathrm{R}_{2}=$ prenyl; $\mathrm{R}_{3}=\mathrm{Me}$ Hymenocardichromene C $\mathrm{R}_{1}=\mathrm{COOH} ; \mathrm{R}_{2}=\mathrm{H} ; \mathrm{R}_{3}=$ prenyl Hymenocardichromene $D \mathrm{R}_{1}=\mathrm{COOH} ; \mathrm{R}_{2}=\mathrm{H} ; \mathrm{R}_{3}=\mathrm{A}$ Hymenocardichromene $E \mathrm{R}_{1}=\mathrm{COOH} ; \mathrm{R}_{2}=\mathrm{H} ; \mathrm{R}_{3}=\mathrm{B}$ Hymenocardichromene $F \mathrm{R}_{1}=\mathrm{COOH} ; \mathrm{R}_{2}=\mathrm{H} ; \mathrm{R}_{3}=\mathrm{C}$

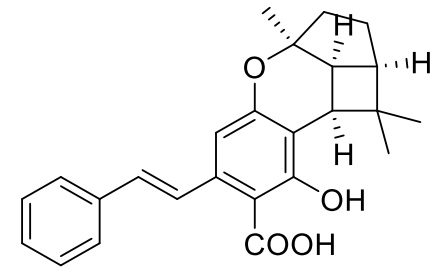

Hymenocardichromanic acid

Figure 6. Structures of chromene and chromane stilbenoids Starks et al. (2014) [70].

Table 9. Antibacterial activity of hymenocardichrom-ene/anes against MRSA-108 S. aureus from Starks et al. (2014) [70].

\begin{tabular}{cc}
\hline Compound & MIC $(\mu \mathrm{g} / \mathrm{mL})$ \\
\hline h. A & $>32$ \\
h. B & 16 \\
h. C & 16 \\
h. D & 16 \\
h. E & 16 \\
h. F & 16 \\
h. acid & 8 \\
Vancomycin * & 2 \\
\hline *Vancomycin was used as positive control.
\end{tabular}

* Vancomycin was used as positive control. 


\subsection{Combretastatins and Their Analogues}

Combretastatins belong to the stilbenes family and include combretastatins, bibenzyls or dihydrostilbenes, phenanthrenes, and macrocyclic lactones. This subgroup of compounds was discovered in the African willow tree Combretum caffrum (Combretaceae), after the first isolation of combretastatin (Figure 7) [32]. Six stilbenoids extracted from the roots of Stemona japonica (Bl.) Miq, which is used in traditional Chinese medicine against insect pests and respiratory diseases, were tested against S. aureus (ATCC 25923), S. epidermidis (ATCC 12228), and E. coli (ATCC 15628). Stilbostemin L, stemanthrene F, and compounds 8 and 9 (Figure 7) displayed significant antibacterial activity (MICs in the range 12.5-50 $\mu \mathrm{g} / \mathrm{mL}$ ) against the tested Staphylococcus strains (Table 10) [71].<smiles>COc1ccc(C[C@@H](O)c2cc(OC)c(OC)c(OC)c2)cc1OC</smiles>

Combretastatin<smiles>[R]c1cc(CCc2c([R5])c([R])cc([R])c2[R5])cc([R])c1[R]</smiles><smiles>COc1cc(O)c2c(c1C)CCc1cc(O)c(C)cc1-2</smiles>

Stemanthrene $\mathrm{F}$

Stilbostemin $J R_{1}, R_{3}, R_{5}, R_{7}=H, R_{2}, R_{6}=O H, R_{4}, R_{8}=O M e$

Stilbostemin $K \mathrm{R}_{1}, \mathrm{R}_{3}, \mathrm{R}_{6}, \mathrm{R}_{8}=\mathrm{H}, \mathrm{R}_{2}, \mathrm{R}_{4}=\mathrm{OH}, \mathrm{R}_{5}, \mathrm{R}_{7}=\mathrm{OMe}$

Stilbostemin $L_{1} R_{1}, R_{3}=O H, R_{2}, R_{4}=M e, R_{5}, R_{7}=O M e, R_{6}, R_{8}=H$

$8 \mathrm{R}_{1}, \mathrm{R}_{5}, \mathrm{R}_{6}, \mathrm{R}_{7}, \mathrm{R}_{8}=\mathrm{H}, \mathrm{R}_{2}, \mathrm{R}_{4}=\mathrm{OH}, \mathrm{R}_{3}=\mathrm{Me}$

$9 \mathrm{R}_{1}, \mathrm{R}_{6}, \mathrm{R}_{7}, \mathrm{R}_{8}=\mathrm{H}, \mathrm{R}_{2}, \mathrm{R}_{4}=\mathrm{OH}, \mathrm{R}_{3}=\mathrm{Me}, \mathrm{R}_{5}=\mathrm{OMe}$

Figure 7. Structures of combretastatin from Shen et al. (2009) [32], stilbostemins and Stemanthrene F. from Yang et al. (2006) [71].

Table 10. Antibacterial activity of stilbostemins, stemanthrene and compounds 8 and $\mathbf{9}$ in MIC values $(\mu \mathrm{g} / \mathrm{mL})$ from Yang et al. (2006) [71].

\begin{tabular}{cccc}
\hline Compound & S. aureus & S. epidermidis & E. coli \\
\hline S. J & $>50$ & $>50$ & $>50$ \\
S. K & $>50$ & $>50$ & $>50$ \\
S. L & 50 & $12.5-25$ & $>50$ \\
S. F & 25 & $12.5-25$ & $>50$ \\
8 & 12.5 & $12.5-25$ & $>50$ \\
9 & 25 & $25-50$ & $>50$ \\
Bakuchiol & 25 & 12.5 & 50 \\
Magnolol & 25 & 12.5 & 50 \\
\hline
\end{tabular}

Bakuchiol and Magnolol were used as positive control agents.

Yang et al. [72] isolated a new bisphenanthrene, 2,2' $, 4,4^{\prime}, 7,7^{\prime}$-hexamethoxy-9, $9^{\prime}, 10,10^{\prime}$-tetrahydro1,1'-biphenanthrene, along with other five known phenanthrene stilbenes (10-13, blestriaren B, blestriaren C) (Figure 8) from the tubers of Bletilla yunnanensis Schltr. (Orchidaceae family), which is largely present in China. The tubers of this plant have long been used to treat pulmonary diseases; thus, their chemical composition was investigated. The isolated compounds were tested against three Gram-positive bacteria, S. aureus, S. epidermidis, and B. subtilis, and two Gram-negative bacteria, E. coli 
and Klebsiella pneumoniae. Blestriarene B and C showed interesting MIC values $(6.25-25 \mu \mathrm{g} / \mathrm{mL})$ against S. aureus and S. epidermidis (Table 11) [72].<smiles>COc1ccc(-c2cc(OC)cc(OC)c2-c2cc(OC)cc3c2CCc2cc(OC)ccc2-3)cc1</smiles><smiles>COc1cc(CCc2cccc(O)c2)cc(O)c1Cc1ccc(O)cc1</smiles>

11<smiles>COc1cc(O)c(-c2c(O)cc(OC)c3c2ccc2cc(O)ccc23)c2c1-c1ccc(O)cc1CC2</smiles>

Blestriaren B<smiles>[R]c1cc2c(ccc3cc(OC)c([R])c(OC)c32)c([R])c1O</smiles>

14a $R_{1}=R_{2}=O H ; R_{3}=H$

$14 b R_{1}=R_{3}=H ; R_{2}=O H$

14c $\mathrm{R}_{1}=\mathrm{H} ; \mathrm{R}_{2}=\mathrm{OMe} ; \mathrm{R}_{3}=\mathrm{OH}$

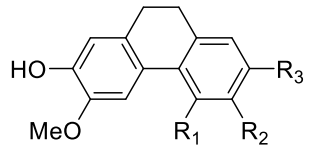

15a $\mathrm{R}_{1}=\mathrm{OMe} ; \mathrm{R}_{2}=\mathrm{H} ; \mathrm{R}_{3}=\mathrm{OH}$ 15b $R_{1}=O H ; R_{2}=R_{3}=O M e$<smiles>COc1cc(O)c(Cc2ccc(O)cc2)c(CCc2cccc(O)c2)c1</smiles>

12<smiles>COc1cc(O)c2c(c1Cc1ccc(O)cc1)CCc1cc(O)ccc1-2</smiles>

16a $\mathrm{R}_{1}=\mathrm{R}_{6}=\mathrm{OMe} ; \mathrm{R}_{2}=\mathrm{R}_{4}=\mathrm{H} ; \mathrm{R}_{5}=\mathrm{OH}$ 16b $R_{1}=R_{2}=R_{3}=O M e ; R_{4}=R_{5}=H ; R_{6}=O H$ 16c $R_{1}=R_{2}=O M e ; R_{3}=R_{6}=O H ; R_{4}=R_{5}=H$ 16d $R_{1}=R_{3}=O M e ; R_{2}=R_{6}=O H ; R_{4}=R_{5}=H$ 16e $R_{1}=R_{2}=R_{3}=O M e ; R_{5}=O H ; R_{4}=R_{6}=H$

Figure 8. Structures of compounds isolated from Bletilla yunnanensis Schltr. from Yang et al. (2016) [72] and from C. hereroense, C. collinum, and C. apiculatum from Katerere et al. (2012) [73].

Table 11. Antimicrobial activity of compounds 10-13 in MIC values, $\mu \mathrm{g} / \mathrm{mL}$ from Yang et al. (2016) [72].

\begin{tabular}{cccccc}
\hline Compound & S. aureus & S.epidermidis & B. subtilis & E. coli & K. pneumoniae \\
\hline 10 & 100 & 200 & 100 & $>200$ & $>200$ \\
11 & 200 & 100 & 200 & $>200$ & $>200$ \\
12 & 200 & 25 & 200 & $>200$ & $>200$ \\
b. B & 6.25 & 25 & 100 & 200 & $>200$ \\
b. C & 25 & $25-50$ & 200 & 200 & $>200$ \\
13 & 20 & 4 & 8 & 2 & $>200$ \\
Chloroamphenicol $^{\text {a }}$ & 4 & Chen & \\
\hline
\end{tabular}

${ }^{\mathrm{a}}$ Chloroamphenicol was used as positive control.

Katerere et al. [73] investigated the antimicrobial activity of a collection of stilbenoids (14-16, Figure 8) extracted from C. hereroense, C. collinum, and C. apiculatum, which are plants belonging to the African Combretaceae and used in Southern Africa to treat several disorders, mainly related to infections. The phenanthrenes 14a, 14b, 15a, and $\mathbf{1 5 b}$ showed moderate activity against Mycobacterium fortuitum and $S$. aureus (MIC $=25 \mu \mathrm{g} / \mathrm{mL}$ ) (Table 12) [73]. 
Table 12. MIC of compounds isolated from African Combretaceae from Katerere et al. (2012) [73].

\begin{tabular}{ccccc}
\hline Compound & E. coli & M. fortuitum & P. vulgaris & S. aureus \\
\hline $14 \mathrm{a}$ & $>100$ & 25 & 100 & 25 \\
$14 \mathrm{~b}$ & $>100$ & 25 & 100 & 25 \\
$14 \mathrm{c}$ & $>100$ & 100 & 100 & 100 \\
$15 \mathrm{a}$ & $>100$ & 25 & 100 & 25 \\
$15 \mathrm{~b}$ & $>100$ & 25 & 100 & 25 \\
$16 \mathrm{a}$ & 100 & 100 & 50 & 25 \\
$16 \mathrm{~b}$ & $>100$ & 100 & 100 & 100 \\
$16 \mathrm{c}$ & $>100$ & $>100$ & $>100$ & $>100$ \\
$16 \mathrm{~d}$ & $>100$ & $>100$ & $>100$ & $>100$ \\
$16 \mathrm{e}$ & $>100$ & 1.56 & 3.12 & 0.78 \\
\hline
\end{tabular}

* Streptomycin was used as positive control.

From the extract of Bletilla striata (Thunb.) Rchb.f. (Orchidaceae) [74], a plant used by traditional Chinese medicine to treat hematemesis, tuberculosis, malignant ulcers, traumatic bleeding, and cold [75], 21 compounds were isolated and evaluated for their antimicrobial activities against MRSA S. aureus ATCC 43300, B. subtilis ATCC 6051, S. aureus ATCC 6538, and E. coli ATCC 11775 (Figure 9, Table 13). Compounds 18a, 19a, 19c, 20, 21, and 23 were shown to be active against $S$. aureus ATCC 6538 (MIC values ranging from 6 to $52 \mu \mathrm{g} / \mathrm{mL}$ ). The methoxy groups seemed to decrease the antibacterial activity (compound 19a vs 19c), and the phenanthrenes were shown to be better than the corresponding dihydrophenanthrenes against MRSA S. aureus (compound 18a versus 19a) [74].

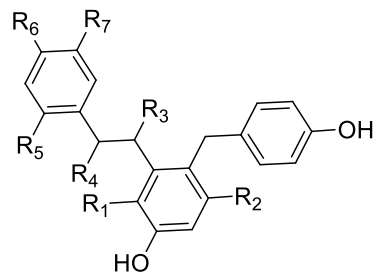

17a $\mathrm{R}_{1}=4-\mathrm{OH}$-benzyl, $\mathrm{R}_{2}=\mathrm{R}_{4}=\mathrm{R}_{7}=\mathrm{OH} \mathrm{R} \mathrm{R}_{3}=\mathrm{R}_{5}=\mathrm{R}_{6}=\mathrm{H}$ 17b $R_{1}=R_{4}=R_{6}=H ; R_{2}=R_{3}=R_{7}=O H ; R_{5}=4-O H$-benzyl 17c $\mathrm{R}_{1}=\mathrm{R}_{3}=\mathrm{R}_{4}=\mathrm{R}_{5}=\mathrm{R}_{7}=\mathrm{H} ; \mathrm{R}_{2}=\mathrm{R}_{6}=\mathrm{OH}$ $17 d R_{1}=R_{3}=R_{4}=R_{5}=H ; R_{2}=R_{7}=O_{3} ; R_{6}=O H$

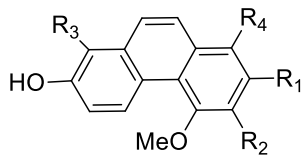

18a $\mathrm{R}_{1}=\mathrm{OH} ; \mathrm{R}_{2}=\mathrm{OCH}_{3} ; \mathrm{R}_{3}=\mathrm{R}_{4}=\mathrm{H}$ 18b $\mathrm{R}_{1}=\mathrm{OCH}_{3} ; \mathrm{R}_{2}=\mathrm{OH} ; \mathrm{R}_{3}=\mathrm{R}_{4}=\mathrm{H}$ 18c $R_{1}=O H ; R_{2}=R_{4}=H ; R_{3}=O C H_{3}$ 18d $\mathrm{R}_{1}=\mathrm{R}_{3}=\mathrm{OCH}_{3} ; \mathrm{R}_{2}=\mathrm{OH} ; \mathrm{R}_{4}=\mathrm{H}$

18e $\mathrm{R}_{1}=\mathrm{OH} ; \mathrm{R}_{2}=\mathrm{H} ; \mathrm{R}_{3}=\mathrm{OCH}_{3} ; \mathrm{R}_{4}=4-\mathrm{OH}$-benzyl $18 f R_{1}=O H ; R_{2}=R_{3}=H ; R_{4}=4-O H$-benzyl

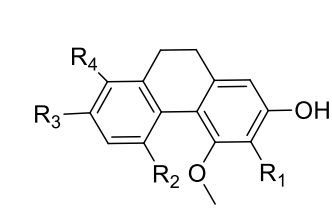

19a $\mathrm{R}_{1}=\mathrm{R}_{2}=\mathrm{R}_{4}=\mathrm{H} ; \mathrm{R}_{3}=\mathrm{OH}$ 19b $R_{1}=R_{2}=H ; R_{3}=O_{3} \mathrm{CH}_{3} ; R_{4}=O H$ 19c $\mathrm{R}_{1}=\mathrm{OCH}_{3} ; \mathrm{R}_{2}=\mathrm{R}_{4}=\mathrm{H} ; \mathrm{R}_{3}=\mathrm{OH}$ 19d $R_{1}=R_{2}=H ; R_{3}=O H ; R_{4}=O_{3}$ 19e $R_{1}=R_{3}=R_{4}=H ; R_{2}=O H$<smiles>COc1cc(O)c(-c2c(O)cc(OC)c3c2CCc2cc(O)ccc2-3)c2c1CCc1cc(O)ccc1-2</smiles><smiles>COc1cc([C@@H]2COc3cc(OC)c4c(c3[C@@H]2O)CCc2cc(O)ccc2-4)cc(O)c1O</smiles>

20<smiles>[R2]c1cc([R2])cc(CCc2cccc(O)c2)c1</smiles><smiles>[R]c1cc2c(c(OC)c1O)/C=C/c1ccccc1OC2=O</smiles>

Sciryagarol I $\mathrm{R}=\mathrm{H}$ Sciryagarol II $\mathrm{R}=\mathrm{OH}$

Figure 9. Structures of compounds extracted from Bletilla striata from Jiang et al. (2019) [74] and Scirpus yagara Ohwi from Liang et al. (2013) [76]. 
Table 13. Minimum inhibitory concentrations (MICs) for selected compounds isolated from Bletilla striata from Jiang et al. (2019) [74].

\begin{tabular}{ccccc}
\hline \multirow{2}{*}{ Compound } & \multicolumn{5}{c}{ MIC $(\mu \mathrm{g} / \mathrm{mL})$} \\
\cline { 2 - 5 } & $\begin{array}{c}\text { S. aureus } \\
\text { ATCC 6538 }\end{array}$ & $\begin{array}{c}\text { B. subtilis } \\
\text { ATCC 6051 }\end{array}$ & $\begin{array}{c}\text { MRSA S. aureus } \\
\text { ATCC 43300 }\end{array}$ & $\begin{array}{c}\text { E. coli } \\
\text { ATCC 11775 }\end{array}$ \\
\hline $18 \mathrm{a}$ & - & 53 & 53 & - \\
$19 \mathrm{a}$ & 26 & 53 & 53 & - \\
$19 \mathrm{c}$ & 53 & - & - & - \\
20 & 26 & - & - & - \\
21 & 52 & - & - & - \\
22 & 52 & - & - & - \\
23 & 6 & - & 3 & 137 \\
Oxacillin $^{\text {a }}$ & 0.078 & 1 &
\end{tabular}

Sciryagarol I and II (Figure 9) are two cis-stilbenoids isolated from the tubers of Scirpus yagara Ohwi (perennial Cyperaceae species), which is used in traditional Chinese medicine. The two compounds showed moderate antibacterial activity against S. aureus $(\mathrm{MIC}=152$ and $79.3 \mu \mathrm{g} / \mathrm{mL}$, respectively,) whereas they were inactive against E. coli [76]. The natural stilbenoid combretastatin inspired the synthesis of numerous Z-stilbene derivatives, which are endowed with various biological properties [77]. Jain et al. [78] synthesised 30 novel para-(substituted phenyl)-2-(substituted phenyl) ethane compounds and evaluated their antibacterial activity against Gram-positive (S. aureus, B. subtilis) and Gram-negative (P. vulgaris, E. coli) strains. Some of the most active synthesised Z-stilbene compounds (25a-c, 26a-b, 27a-b) are reported in Figure 10. All compounds were moderately active compared to the standard ciprofloxacin, and $26 \mathrm{~b}$ turned out to be the most potent molecule of the series against all four bacteria [78]. In 2013, a new one-pot diasteroselective synthesis of polyhydroxy Z-stilbenes was conceived by Miliovsky et al. [79] to prepare six new compounds. The antimicrobial activity of the novel molecules (28a-e, 29, Figure 10) was evaluated. Compounds 28a-e did not show any antibacterial activity against the four bacterial strains tested, whereas the dimethylated derivative 29 exhibited $44 \%$ of the inhibitory effect of the standard amikacin on the growth of B. subtilis ATCC 6633 at the same concentration [79].<smiles>[R]c1ccc(/C=C\c2ccc([R])c([R])c2[R])cc1</smiles>

25a, R=OH, R $1=\mathrm{H}, \mathrm{R}_{2}=\mathrm{OCH}_{3}, \mathrm{R}_{3}=\mathrm{OCH}_{3}$ 25b, R=Cl, $\mathrm{R}_{1}=\mathrm{H}, \mathrm{R}_{2}=\mathrm{OCH}_{3}, \mathrm{R}_{3}=\mathrm{OCH}_{3}$ 25c, $\mathrm{R}=\mathrm{Cl}, \mathrm{R}_{1}=\mathrm{H}, \mathrm{R}_{2}=\mathrm{OH}, \mathrm{R}_{3}=\mathrm{OCH}_{3}$<smiles>[R]NC(=O)/C(=C/c1ccc([R3])c([R])c1[R])c1ccc([R])cc1</smiles>

27a, $\mathrm{R}^{\prime}=\mathrm{CH}_{3}, \mathrm{R}=\mathrm{OH}, \mathrm{R}_{1}=\mathrm{H}, \mathrm{R}_{2}=\mathrm{OCH}_{3}, \mathrm{R}_{3}=\mathrm{OCH}_{3}$ 27b, $\mathrm{R}^{\prime}=\mathrm{C}_{2} \mathrm{H}_{5}, \mathrm{R}=\mathrm{OH}, \mathrm{R}_{1}=\mathrm{H}, \mathrm{R}_{2}=\mathrm{OCH}_{3}, \mathrm{R}_{3}=\mathrm{OCH}_{3}$<smiles>[R]c1ccc(/C(=C/c2ccc([R3])c([R])c2[R])C(=O)O)cc1</smiles>

26a, R=H, R $=\mathrm{H}, \mathrm{R}_{2}=\mathrm{OCH}_{3}, \mathrm{R}_{3}=\mathrm{OCH}_{3}$ 26b, R=H, $\mathrm{R}_{1}=\mathrm{H}, \mathrm{R}_{2}=\mathrm{OH}, \mathrm{R}_{3}=\mathrm{OCH}_{3}$<smiles>[R]c1cc(/C=C(/C)c2cc(O)c(O)cc2C(=O)O)cc([R])c1[R]</smiles>

28a, $R_{1}, R_{2}, R_{3}=H$

28b, $\mathrm{R}_{1}, \mathrm{R}_{3}=\mathrm{H} ; \mathrm{R}_{2}=\mathrm{OH}$

28c, $\mathrm{R}_{1}, \mathrm{R}_{2}=\mathrm{OH} ; \mathrm{R}_{3}=\mathrm{H}$

28d, $\mathrm{R}_{1}, \mathrm{R}_{2}, \mathrm{R}_{3}=\mathrm{OH}$

28e, $\mathrm{R}_{1}, \mathrm{R}_{3}=$ tert-Bu, $\mathrm{R}_{2}=\mathrm{OH}$<smiles>COc1cc(C(=O)O)c(/C(=C\c2cc(C(C)(C)C)c(O)c(C(C)(C)C)c2)C(=O)O)cc1OC</smiles>

29
Figure 10. Structures of stilbene derivatives from Jain et al. (2015), Miliovsky et al. (2013), and More et al. (2015) [78-80]. 
Inspired by the natural product honokiol, reported for its inhibitory activity against the oral bacterium S. mutans, and used in Chinese, Japanese, and Korean traditional medicine for centuries [81], Solinski et al. [82] carried out the synthesis of honokiol analogues (Figure 11). The dihydrostilbene 30 was identified to highly enhance the antibacterial effects of the natural precursor with an MIC value of 2 $\mu \mathrm{M}(66 \mathrm{ng} / \mathrm{mL})$, and it revealed a strong bactericidal effect $(\mathrm{MBC}=4 \mu \mathrm{M})$ on $S$. mutans [82]. In 2020, the same research group performed further SAR studies on 30, designing 66 new analogs in order to understand the structural features crucial to the antibacterial activity on S. mutans planktonic growth. The MIC values of the synthesised compounds (Figure 11) revealed that alkyl groups on each aromatic ring were fundamental for the activity, and tert-butyl substituents in the number of two were found to be the optimum. Even in this case, the hydroxy functions resulted to be important structural features, since double alkylation of the phenolic groups caused a drastic drop in activity (35). However, the potency was retained when one hydroxy group was alkylated with a methyl group (34). Slight modification in the substitution pattern did not lead to any loss of activity $(40,42)$, but the shift of the hydroxy groups to the ortho positions of the aromatic rings significantly decreased the potency (46), which was probably because of a misalignment of the hydrogen bonding postulated to play a key role in the interaction with the target. Regarding insight into the mechanism of action, $\mathbf{3 0}$ was found to interfere with the membrane stability and permeability without affecting membrane potential. Moreover, 30 showed a therapeutic index that was fourfold higher compared to cetylpyridinium chloride (CPC), which is a commercial antimicrobial used in toothpaste, mouthwashes, throat, and breath sprays, establishing the potential of further development of the dihydrostilbene 30 scaffold for oral care products [83].

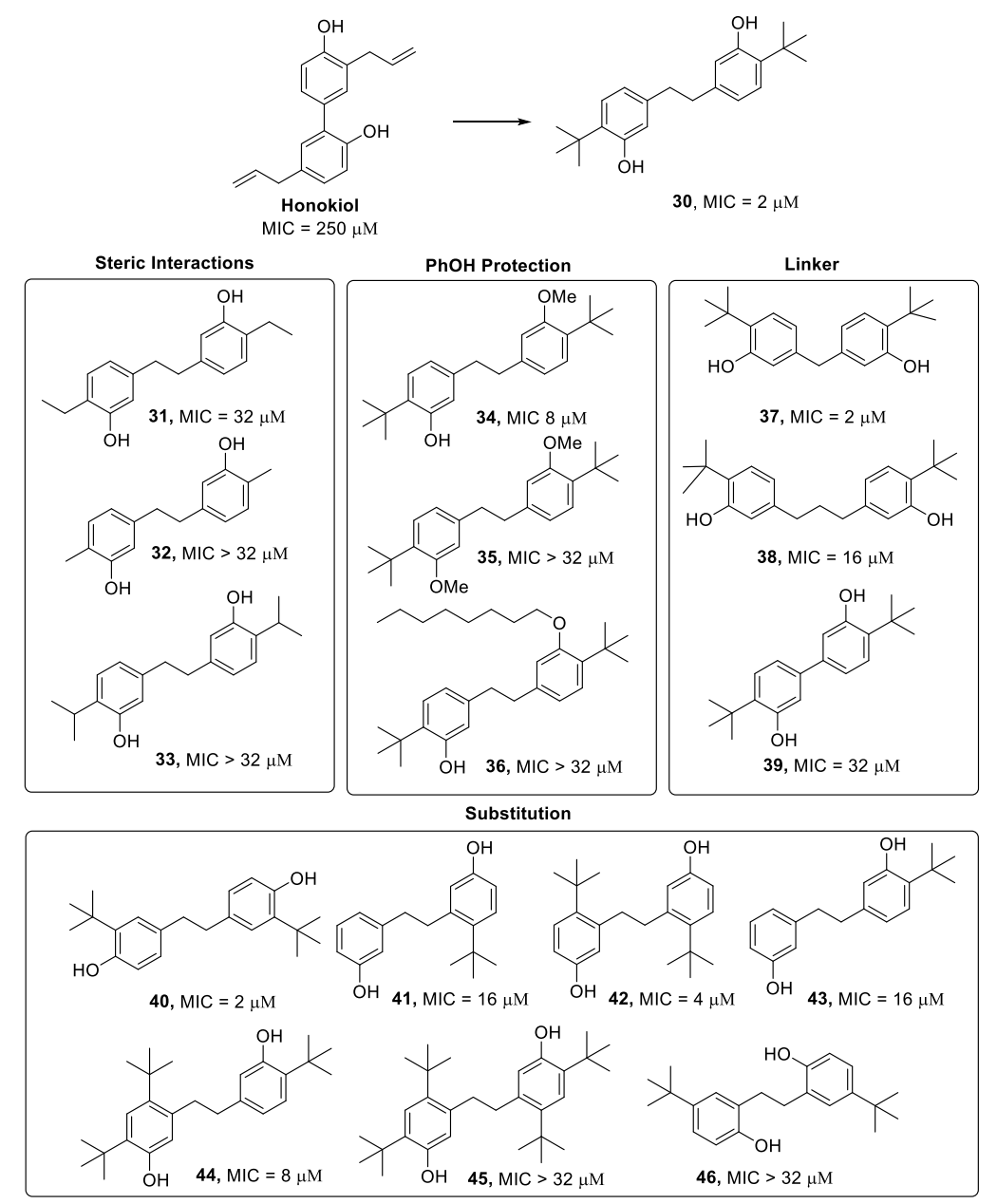

Figure 11. Structures of honokiol and analogues from Solinski et al. (2018) [82] and Ochoa et al. (2020) [83]. 
Recent studies have reported the preparation of cyclophanes constituted of phenothiazine units [84] with photoluminescence and electrochemical characteristics [85,86]. To obtain supramolecular systems with fluorescent sensing features useful in biology, Kanagalatha et al. [87] synthesised new phenothiazine-based fluorescent stilbenophanes $(47,48 a-d)$ and chiral phenothiazinophanes $(49 a-c)$ (Figure 12), and they tested them against a panel of bacteria (S. aureus, S. pneumoniae, E. coli, K. pneumonia, P. vulgaris, S. typhi, and S. flexner). The stilbenophane $48 \mathrm{~d}$, with six phenothiazine units, was the best compound of the series, showing zone of inhibition diameters of $26.8 \mathrm{~mm}$ in S. pneumoniae (Gram-positive bacterium) and $23.4 \mathrm{~mm}$ in K. pneumoniae (Gram-negative bacterium) at the concentration of $50 \mu \mathrm{g} / \mathrm{mL}$. This finding suggested a positive correlation between the increasing number of phenothiazine units and the antimicrobial effect [87].

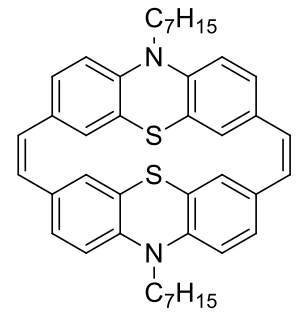

47

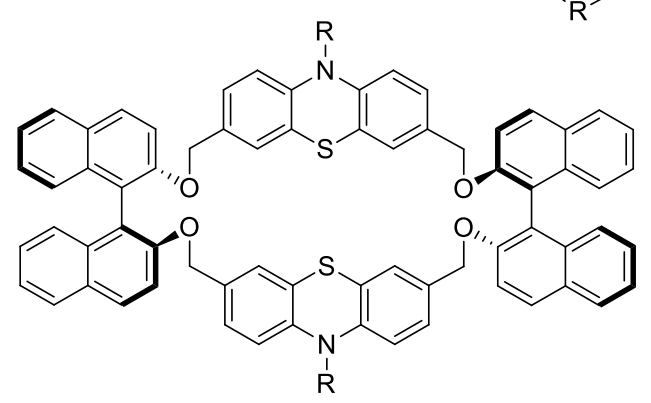

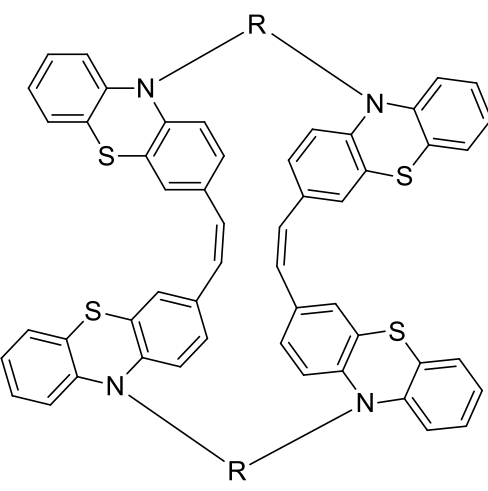

$48 a, R=$<smiles>CCc1cc(OC)c(CC)cc1OC</smiles>

$48 b, R=$<smiles>CCc1ccc(-c2ccc(CC)cc2)cc1</smiles>

$48 c, R=$<smiles>CCc1ccc(-c2cccc(-c3ccc(CC)cc3)c2)cc1</smiles>

48d, $R=$<smiles>CCc1ccc2c(c1)Sc1cc(CC)ccc1N2CC</smiles>

Figure 12. Structures of phenothiazinophanes from Kanagalatha et al. (2015) [87].

\subsection{Nitrogen and Sulfur-Containing Stilbene Derivatives}

Rezaei-Seresht et al. [88] evaluated the antibacterial activity of five novel azo dye-stilbene hybrid compounds, consisting of a phenolic moiety connected to a stilbene entity by an azo group (Figure 13), against eight Gram-negative bacteria (Pseudomonas aeruginosa ATCC27853, Escherichia coli ATCC25922, Staphylococcus coagulase, Citrobacter frurdii ATCC8090, Enterobacter aeruginosa ATCC21754, Acinetobacer baumannii ATCC13883, Serratia marcescens ATCC8100, Klebsiella pneumoniae ATCC13883) and one Gram-positive bacterium (Streptococcus pneumoniae ATCC 49619) by disc diffusion assay. Only the azo compounds 50c and 50d showed antibacterial efficacy against one Gram-negative P. aeruginosa with diameters of inhibition zones of 8.4 and $7.3 \mathrm{~mm}$, respectively, and the Gram-positive S. pneumoniae (diameters of inhibition zones 9.7 and $10.1 \mathrm{~mm}$, respectively). Interestingly, both active compounds bear two hydroxy groups, which presumably play a key role in the bacterial growth inhibition displayed by 50c and 50d [88]. 


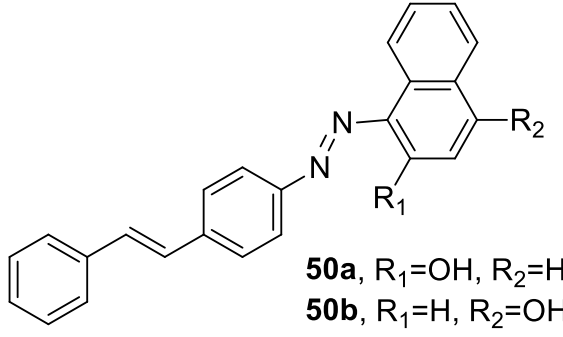<smiles>[R2]c1cc(/N=N/c2ccc(O)cc2)cc([R2])c1O</smiles><smiles>[R]c1ccc(/C=N/NC(=O)c2ccccc2/C=C/c2ccccc2)c([R2])c1[R]</smiles>

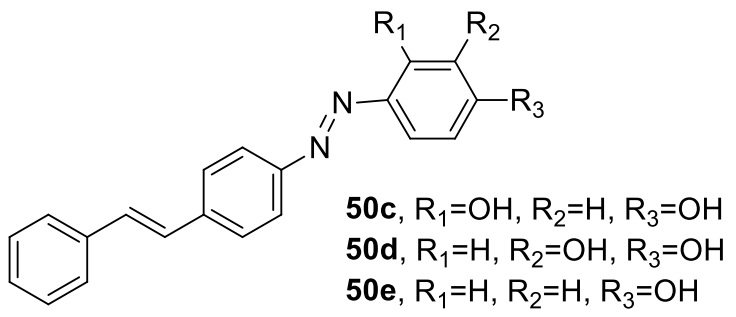
51a, $\mathrm{R}_{1}=\mathrm{CH}_{2} \mathrm{CH}_{3}, \mathrm{R}_{2}=\mathrm{H}$
51b, $\mathrm{R}_{1}=\mathrm{CH}_{2} \mathrm{CH}=\mathrm{CH}_{2}, \mathrm{R}_{2}=\mathrm{H}$
51c, $\mathrm{R}_{1}=\mathrm{CH}_{2} \mathrm{CH}_{2} \mathrm{CH}_{3}, \mathrm{R}_{2}=\mathrm{H}$
51d, $\mathrm{R}_{1}=\mathrm{CH}_{3}, \mathrm{R}_{2}=\mathrm{CH}_{3}$
51e, $\mathrm{R}_{1}=\mathrm{CH}_{3}, \mathrm{R}_{2}=\mathrm{CH}_{2} \mathrm{CH}=\mathrm{CH}_{2}$
52a, $\mathrm{R}_{1}=\mathrm{H}, \mathrm{R}_{2}=\mathrm{H}, \mathrm{R}_{3}=\mathrm{H}$
52b, $\mathrm{R}_{1}=\mathrm{Cl}, \mathrm{R}_{2}=\mathrm{H}, \mathrm{R}_{3}=\mathrm{H}$
52c, $\mathrm{R}_{1}=\mathrm{H}, \mathrm{R}_{2}=\mathrm{H}, \mathrm{R}_{3}=\mathrm{Cl}$
52d, $\mathrm{R}_{1}=\mathrm{OH}, \mathrm{R}_{2}=\mathrm{H}, \mathrm{R}_{3}=\mathrm{H}$
52e, $\mathrm{R}_{1}=\mathrm{H}, \mathrm{R}_{2}=\mathrm{H}, \mathrm{R}_{3}=\mathrm{OH}$
52f, $\mathrm{R}_{1}=\mathrm{H}, \mathrm{R}_{2}=\mathrm{NO}_{2}, \mathrm{R}_{3}=\mathrm{H}$
52g, $\mathrm{R}_{1}=\mathrm{H}, \mathrm{R}_{2}=\mathrm{H}, \mathrm{R}_{3}=\mathrm{NO}_{2}$
52h, $\mathrm{R}_{1}=\mathrm{H}, \mathrm{R}_{2}=\mathrm{OCH}_{3}, \mathrm{R}_{3}=\mathrm{OH}$

Figure 13. Nitrogen-containing stilbenes tested against Gram-negative and Gram-positive bacteria from Rezaei-Seresht et al. (2018) [88] and from Iqbal et al. (2018) [89].

Piotto et al. [90] designed and synthesised a small collection of azobenzenes, containing two nitrogen atoms in place of the olefinic carbons of the stilbenoids, in order to obtain novel compounds with higher antimicrobial activity and reduced toxicity. Five azobenzenes (51a-e, Figure 13), resulting from a virtual screening campaign and characterised by the lowest toxicity profiles in silico, were synthesised. The compounds were tested for the antimicrobial and antibiofilm activities to evaluate their application in polymer matrix for biomedical devices and food packaging. All the azo compounds showed higher antibacterial activity against $S$. aureus, L. monocytogenes, S. typhimurium, P. aeruginosa than resveratrol. Moreover, 51a-c and 51e were able to destroy more than $60 \%$ of pre-formed biofilms at a concentration of $30 \mu \mathrm{g} / \mathrm{mL}$ [90]. A small collection of eight E-stilbene azomethines (52a-h, Figure 13) was synthesised by Mizoroki-Heck reaction and tested for antimicrobial activity [89]. Compound $52 \mathrm{~g}$ was the most active compound of the collection, with MIC values of $0.22 \mathrm{mg} / \mathrm{mL}, 0.07 \mathrm{mg} / \mathrm{mL}$, $0.10 \mathrm{mg} / \mathrm{mL}$, and $0.06 \mathrm{mg} / \mathrm{mL}$ on E. coli (ATCC 25922), S. aureus (ATCC 25923), K. pneumoniae (ATCC 10031), and B. subtilis (ATCC 9637), respectively. Moreover, 52g displayed stronger bactericidal effects than cefradine, the standard drug used as reference antibiotic. In addition, compound 52f, bearing a nitro group at the meta position, exhibited good inhibition growth of the bacteria tested. These results highlighted the importance of electron-withdrawing groups, such as nitro group, for the antimicrobial effect in this series of compounds [89]. A novel class of molecules defined as conjugated oligoelectrolytes (COEs), which are constituted of a conjugate backbone and terminal polar pendant groups, was developed to mimic the strategic features of antimicrobial peptides (AMPs) [91]. Zhou et al. [92] designed and synthetised three CEOs (53a-c, Figure 14), consisting of a stilbene core linked to two terminal ammonium groups by alkyl chains of different length. The compounds were tested on E. coli K12 strain, the pathogenic E. coli UTI89, and on the Gram-positive E. faecalis OG1RF. The antimicrobial activity resulted to increase with increasing the alkyl chain length. The MIC values for E. coli $\mathrm{K} 12$ were 128, 16, and $4 \mu \mathrm{g} / \mathrm{mL}$ for 53a, 53b, and 53c, respectively. Moreover, 53c was active against both Gram-positive and Gram-negative bacteria and exhibited a high cell uptake of $72 \%$, demonstrating a positive correlation between cell uptake and antimicrobial activity [92]. 

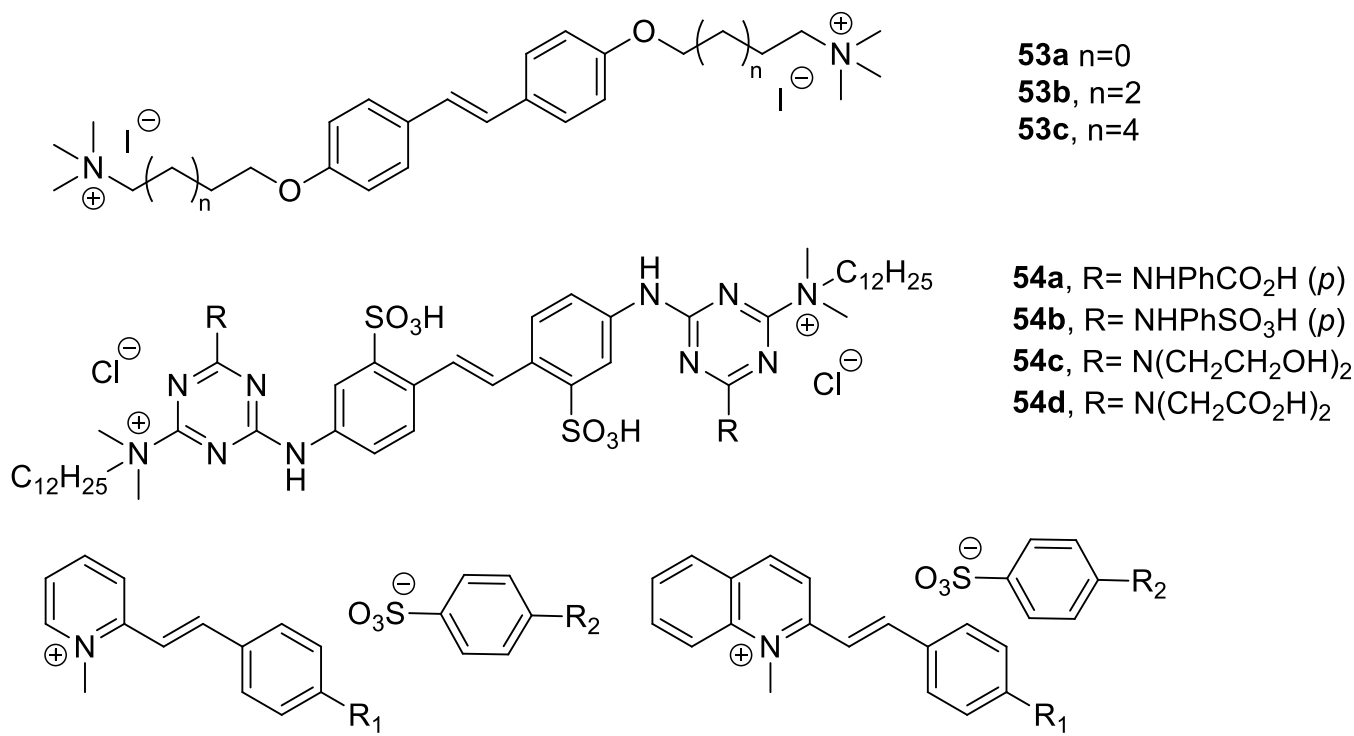

55a $\mathrm{R}_{1}=\mathrm{N}\left(\mathrm{CH}_{3}\right)_{2}, \mathrm{R}_{2}=\mathrm{CH}_{3}$ 55b $\mathrm{R}_{1}=\mathrm{OEt}, \mathrm{R}_{2}=\mathrm{CH}_{3}$ 56a, $\mathrm{R}_{1}=\mathrm{N}\left(\mathrm{CH}_{3}\right)_{2}, \mathrm{R}_{2}=\mathrm{CH}_{3}$ 56b, $\mathrm{R}_{1}=\mathrm{N}\left(\mathrm{CH}_{3}\right)_{2}, \mathrm{R}_{2}=\mathrm{Br}$ 56c $\mathrm{R}_{1}=\mathrm{N}\left(\mathrm{CH}_{3}\right)_{2}, \mathrm{R}_{2}=\mathrm{Cl}$ 56d $\mathrm{R}_{1}=\mathrm{OEt}, \mathrm{R}_{2}=\mathrm{OCH}_{3}$

Figure 14. Chemical structures of ammonium salt-containing stilbenes from Zhou et al. (2018), Wan et al. (2017), and Chanawanno et al. (2010) [92-94].

Stilbene derivatives are optical whitening agents, absorbing invisible ultraviolet (UV) light at wavelengths below $400 \mathrm{~nm}$ and emitting violet-blue fluorescence in the UV-visible region, thus providing brightness and whiteness to a matrix [95]. However, stilbenes cis/trans isomerisation may occur upon exposure to sunlight, leading to fluorescence reduction. Therefore, Wan et al. [93] conceived novel stilbene derivatives bearing long-chain alkyl quaternary salts, in order to obtain optical whitening agents that are more stable to light and endowed with antibacterial activity. Four novel stilbene-12 alkyl quaternary ammonium salts, 54a-d (Figure 14), were synthetised and tested for their optical whitening performance and for the antimicrobial potency against $S$. mutans UA159, E. coli ATCC 25922, and C. albicans 5313a. All the synthesised derivatives exhibited efficient whitening effect on cotton fiber, high fastness and stability to light, and good antibacterial activity. Compound 54d resulted to be the most potent molecule, with $\mathrm{MIC}_{50}$ values of 16 and $4 \mu \mathrm{g} / \mathrm{mL}$ against E. coli and C. albicans, respectively [93]. In 2010, Chanawanno and colleagues [94] prepared other quaternary ammonium compounds (QACs) with a stilbene scaffold. A collection of 20 pyridinium and quinolinium stilbene benzenesulfonates was designed, synthesised, and tested for the antibacterial effects on the Gram-positive bacteria methicillin-resistant S. aureus (MRSA), S. aureus, B subtilis, vancomycin-resistant E. faecalis, E. faecalis, and on the Gram-negative bacteria P. aeruginosa, S. typhi, and $S$. sonnei. Besides the pyridinium and quinolinium rings, the synthesised derivatives differed in the ethoxy and dimethylamino substituents on the phenyl ring (Figure 14). All the compounds exerted antibacterial activity against at least one of the tested strains, indicating that they were more effective against Gram-positive than Gram-negative bacteria. The quinolinium and pyridinium moieties seemed to play a key role in the activity. Quinolinium headgroup-containing compounds were more potent than the pyridinium derivatives, especially against MRSA strains. In particular, 56a-c were the most potent molecules with MIC values of $2.34 \mu \mathrm{g} / \mathrm{mL}$ against all tested Gram-positive microorganisms, indicating that they were more active than the standard quaternary ammonium disinfectant (benzalkonium chloride) and vancomycin. Conversely, 56a-c were inactive against all Gram-negative bacteria, except for S. sonnei. Notably, quinolinium stilbene benzenesulfonates were 2-4 times more active than the corresponding iodide salts. In addition, the dimethylamino derivatives 
resulted to be more potent than the corresponding ethoxy-containing compounds [94]. The natural stilbenoid (E)-3-hydroxy-5-methoxystilbene (Figure 15), which has been isolated from the leaves of Comptonia peregrina (L.) Coulter, was found to exert antimicrobial activity against several clinically relevant Gram-positive bacteria, including MRSA and vancomycin-resistant enterococci (VRE) strains with MIC values of 32 and $16 \mu \mathrm{g} / \mathrm{mL}$, respectively [96]. Therefore, Kabir et al. [96] performed SAR studies on (E)-3-hydroxy-5-methoxystilbene, synthesising, 22 analogues with modified aryl rings (57) or extended by a heteroatom to build $(E)$-phenoxystirenes $(\mathbf{5 8 a}, \mathbf{5 9})$ and $(E)$-phenothiostyrenes $(\mathbf{5 8 b})$ (Figure 15). None of the analogs was effective against the Gram-negative E. coli, as the natural precursor. On the other hand, the natural stilbenoid and its analogs bearing a meta-hydroxy group (e.g., 57, 58a-b, 59) exhibited good inhibitory effects against the Gram-positive bacteria MRSA, S. aureus, B. cereus, M. smegmatis, with MIC values ranging from 16 to $64 \mu \mathrm{g} / \mathrm{mL}$, thus confirming the importance of at least one free hydroxy group for the antibacterial activity [96].<smiles>COc1cc(O)cc(/C=C/c2ccccc2)c1</smiles><smiles>COc1cc(O)cc(/C=C/c2cccs2)c1</smiles><smiles>[R16][13CH2]c1cc(O)cc(OC)c1</smiles>

(E)-3-Hydroxy-5-methoxystilbene<smiles>COc1cc(/C=C/c2ccc(OCc3cn(-c4ccc(C(=O)O)cc4)nn3)cc2)cc(OCc2cn(CC(C(=O)O)C(=O)O)nn2)c1</smiles>

Figure 15. (E)-3-Hydroxy-5-methoxystilbene and synthetic analogues from Kabir et al. (2008) [96] and from Tang et al. (2019) [97].

Considering the antibacterial activity of pterostilbene against methicillin-resistant S. aureus (MRSA) [98], Tang and colleagues [97] designed and synthesised a collection of 20 pterostilbene analogues linked to a $-1,2,3$ triazole moiety to increase the interactions with targets and to raise the water solubility of compounds [99]. The obtained derivatives (60-62, Figure 15), sharing a carboxylic acid moiety, were evaluated against MRSA and VISA (vancomycin-intermediate S. aureus) strains. All the compounds exhibited anti-MRSA activity, and 60 turned out to be the most active molecule, with MIC values in the range of $1.2-2.4 \mu \mathrm{g} / \mathrm{mL}$ and MBC values in the range of $19.5-39 \mu \mathrm{g} / \mathrm{mL}$. SAR studies highlighted the importance of the presence of the carboxylic moiety linked by an appropriate spacer to the triazole ring. In particular, the activity improved by increasing the length of the alkyl chain as a spacer. The optimum of activity was reached when a phenyl group was used as a spacer. The active compounds were found to inhibit the activity of DNA polymerase in MRSA strains. Docking studies of compound 60 showed that the carboxylic group, the triazole moiety, and the oxygen of the phenol ring formed hydrogen bonds with Val320, Lys450, and Arg435 of DNA polymerase (PDB: 4b9t), whereas the pterostilbene scaffold was involved in hydrophobic interactions with Asp409, Pro424, Asp425, and Glu426 outside the DNA polymerase pocket. These findings rationalised the SAR and biological results obtained [97]. 


\section{Oligostilbenoids}

Oxidative radical coupling and Friedel-Crafts reactions of two to eight units of resveratrol or other stilbene monomers yield more complex 3D structures, which occur in nature as dimers, trimers, tetramers, and higher-order oligomers (Figures 16-19) [32,100,101].

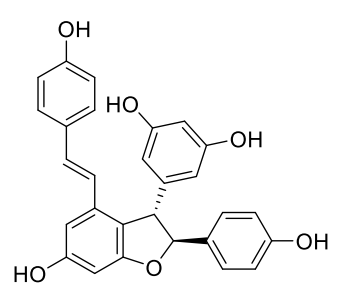

(士)- $\varepsilon$-Viniferin<smiles>Oc1ccc(CCc2cc(O)cc3c2[C@@H](c2cc(O)cc(O)c2)[C@@H](c2ccc(O)cc2)O3)cc1</smiles>

(士)-Hydrogenated- $\varepsilon$-viniferin<smiles>COc1ccc(/C=C/c2cc(OC)cc3c2[C@@H](c2cc(OC)cc(OC)c2)[C@@H](c2ccc(OC)cc2)O3)cc1</smiles>

Pentamethylated-(士)- $\varepsilon$-viniferin

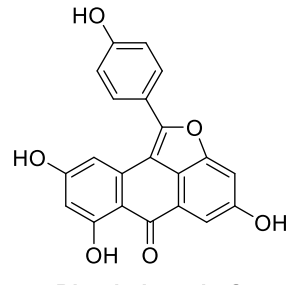

Diptoindonesin G

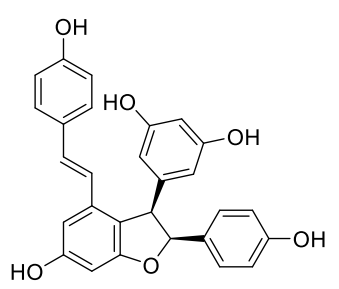

$(E)$ - $\omega$-Viniferin

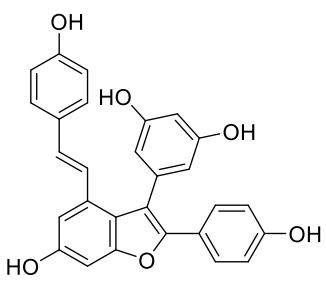

Viniferifuran

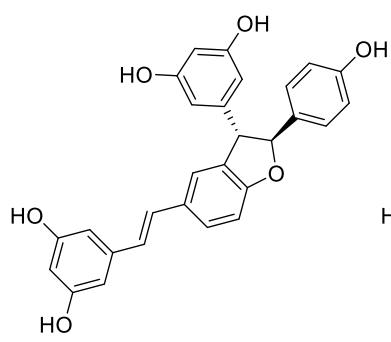

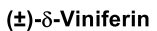

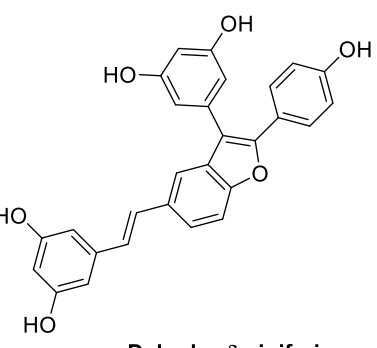

Dehydro- $\delta$-viniferin

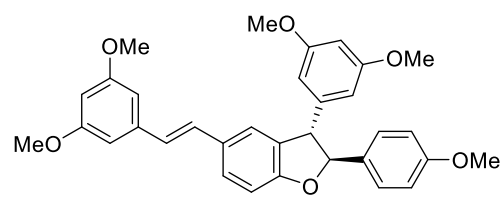

(士)-Pterostilbene-trans-dehydrodimer

Pallidol

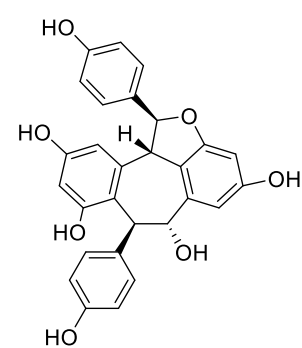

Ampelopsin A

Figure 16. Structures of oligomeric stilbenoids from Shen et al. (2009) [32], Keylor et al. (2015) [100], and Sáez et al. (2018) [101]. 

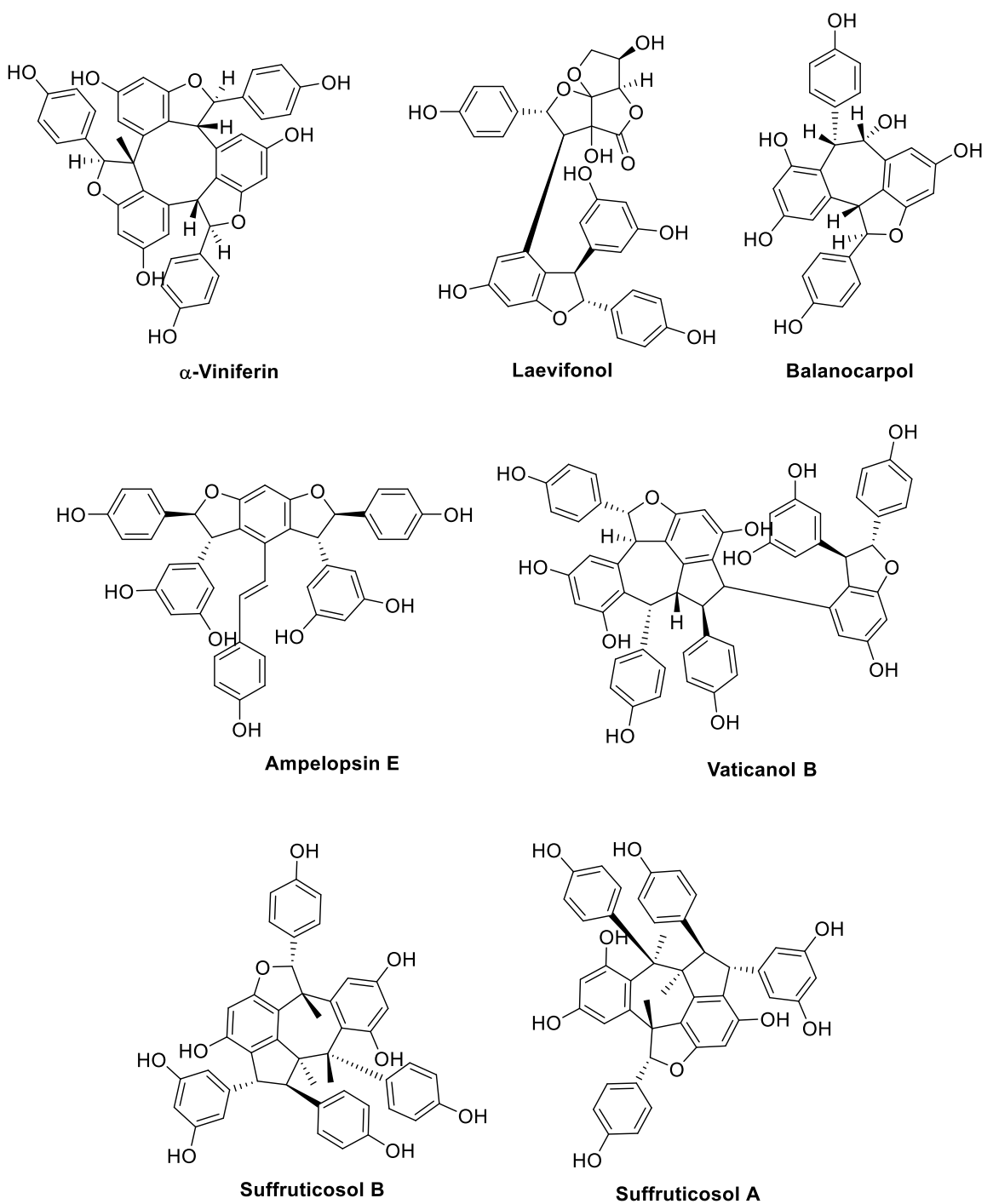

Figure 17. Structures of oligomeric stilbenoids from Shen et al. (2009) [32], Keylor et al. (2015) [100], and Sáez et al. (2018) [101]. 


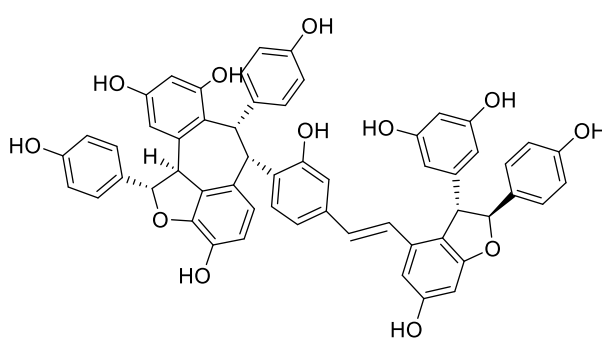

2-r-Viniferin

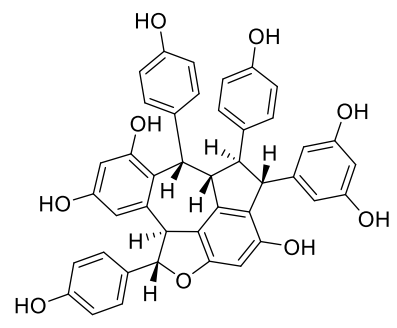

Amurensin G

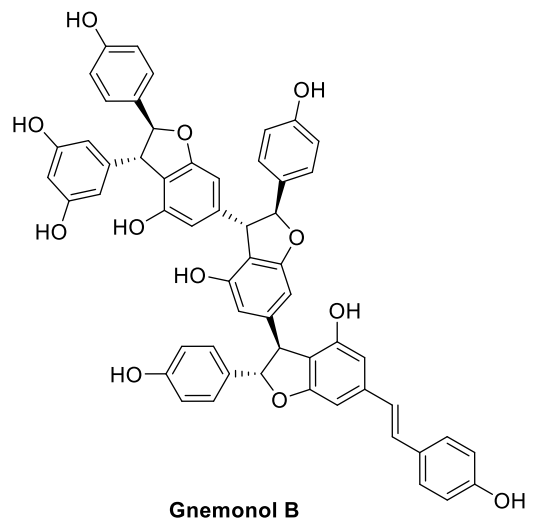

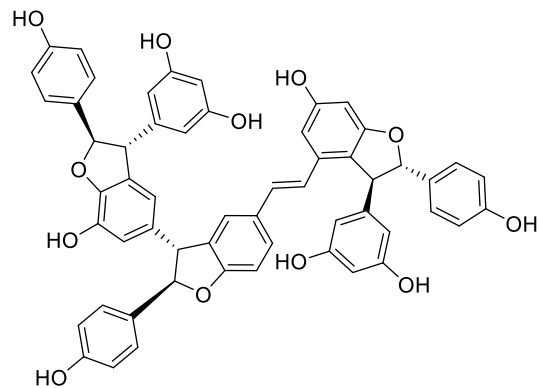

Vitisin B
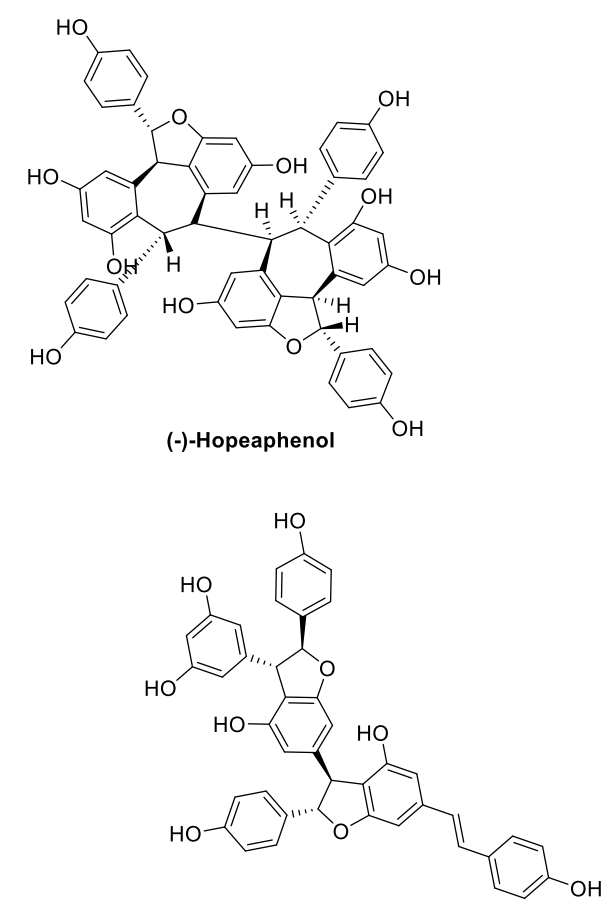

Gnetin E

Figure 18. Structures of oligomeric stilbenoids from Shen et al. (2009) [32], Keylor et al. (2015) [100], and Sáez et al. (2018) [101].

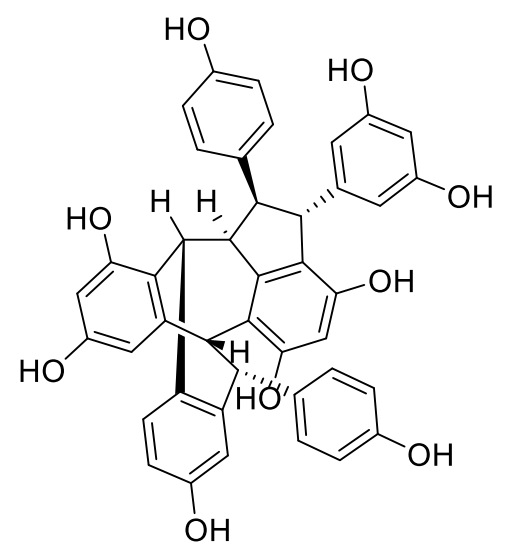

Vaticanol G<smiles>Oc1ccc(C2Cc3cc(O)c(/C=C/c4ccc5c(c4)[C@@H](c4ccc(O)cc4)C(c4ccc(O)cc4)C5)cc3[C@@H](c3cc(O)cc(O)c3)[C@H]2c2ccc(O)cc2)cc1</smiles>

Heyneanol A

Figure 19. Structures of oligomeric stilbenoids from Shen et al. (2009) [32], Keylor et al. (2015) [100], and Sáez et al. (2018) [101]. 
Gnemonol B and gnetin E (Figure 18), isolated from gnetaceous plants, were tested against vancomycin-resistant enterococci (VRE) and methicillin-resistant Staphylococcus aureus (MRSA) strains, resulting in MIC values ranging from 6.25 to $25 \mu \mathrm{g} / \mathrm{mL}$ [102]. However, both compounds were found to be inactive against Gram-negative bacteria, including E. coli, Proteus vulgaris, Serratia marcescens, K. pneumoniae, and P. aeruginosa [103]. Peng et al. [104] discovered the potent antimicrobial activity of heyneanol A (Figure 19), which was isolated from the root extracts of the wild grape Vitis thunbergii (var. taiwaniana). In particular, heyneanol A was found to be remarkably active against MRSA strains with a MIC value of $2 \mu \mathrm{g} / \mathrm{mL}$, which is comparable with that of vancomycin, besides exerting inhibitory growth effects on all tested Gram-positive bacteria (Enterococcus faecium, S. aureus, S. agalactiae, and S. pyogenes) with MIC values ranging from 2 to $4 \mu \mathrm{g} / \mathrm{mL}$ [104]. The resveratrol tetramer (-)-hopeaphenol (Figure 18), isolated from the leaf extracts of two Papua New Guinean rainforest plants, Anisoptera thurifera and A. polyandra, was investigated as an inhibitor of Type III secretion systems (T3SSs), constituting a conserved virulence system in Gram-negative pathogens [105]. Through T3SS action, bacteria are able to secrete and inject different virulence effector proteins into the host cell, inhibiting immunity response and facilitating the invasion and the proliferation of the bacteria into the eukaryotic cell [106]. In particular, at concentrations ranging from 3.3 to $100 \mu \mathrm{M},(-)$-hopeaphenol inhibited dose-dependently and irreversibly the secretion of Yops (Yerninia outer proteins), the effector proteins of Yersinia pseudotuberculosis, likely covalently binding T3SS on the bacterial surface and without affecting the bacterial growth. At the concentration of $100 \mu \mathrm{M}$, the tetramer inhibited also T3SS of the superbug P. aeruginosa in infected HeLa cells and bound covalently to Chlamydia trachomatis, preventing the infection of pretreated HeLa cells. Notably, the compound did not affect the growth inhibition of any strain tested, confirming its activity as a selective inhibitor of the virulence T3SS [105].

Five resveratrol oligomers, including $\varepsilon$-viniferin (Figure 16), suffruticosol A, suffruticosol B (Figure 17), vitisin A, and vitisin B (Figure 18) were investigated for their antihemolytic activity on S. aureus [107]. The tetramer vitisin B was found to be the most active compound of the series, inhibiting hemolysis at 1 and $2 \mu \mathrm{g} / \mathrm{mL}$ by more than $70 \%$ and $95 \%$, respectively. $\varepsilon$-Viniferin and vitisin A were found to be very effective at $10 \mu \mathrm{g} / \mathrm{mL}$, whereas suffriticosol B and A were less potent [107]. From D. lanceolate stem barks, five oligomers were isolated: $\varepsilon$-viniferin (Figure 16), balanocarpol, $\alpha$-viniferin, vaticanol B (Figure 17), and hopeaphenol (Figure 18) [108]. $\varepsilon$-Viniferin was found to be the most effective compound against $E$. coli, whereas balanocarpol was the most potent against $S$. aureus (Table 14). Both $\varepsilon$-viniferin and balanocarpol are stilbene dimers with a smaller molecular size than the trimer $\alpha$-viniferin and the tetramers vaticanol B and hopeaphenol. Therefore, in this case, the molecular size seemed to cause a different penetration into the microorganism, affecting the antibacterial activity [108].

Table 14. Antibacterial activity of the isolated compounds from Sahidin et al. (2017) [108].

\begin{tabular}{ccc}
\hline Compound & \multicolumn{2}{c}{ Diameter of Inhibition Zone (Mean \pm SD) ${ }^{*}$} \\
\cline { 2 - 3 } & E. coli & S. aureus \\
\hline Balanocarpol & $9 \pm 0.17$ & $13 \pm 0.12$ \\
E-Viniferin & $11 \pm 0.22$ & $7 \pm 0.17$ \\
$\alpha$-Viniferin & $8 \pm 0.20$ & $8 \pm 0.16$ \\
Vaticanol B & $5 \pm 0.12$ & $4 \pm 0.14$ \\
Hopeaphenol & $6 \pm 0.16$ & $8 \pm 0.11$ \\
Tetracycline & $14 \pm 0.14$ & $19 \pm 0.12$
\end{tabular}

* SD: standard deviation, triplicates; diameter of Whatman paper $=6 \mathrm{~mm},($ Balanocarpol $)=(\varepsilon$-Viniferin $)=$ $(\alpha$-Viniferin $)=($ Vaticanol B $)=($ Hopeaphenol $)=10,000 \mu \mathrm{g} / \mathrm{mL} ;$ control $($ tetracyclin $30 \mu \mathrm{g} /$ disc $)$.

A series of oligostilbenes was extracted from the leaves of Vitis amurensis (Rupre.) Vitaceae [109] and evaluated for their antimicrobial activity against S. mutans and S. sanguis (Table 15). (+)-Ampelopsin $A$ and $F$ (Figure 16) did not show any antimicrobial effect, whereas $\mathcal{E}$-viniferin (Figure 16) was the most active compound with MIC values of 25 and $12.5 \mu \mathrm{g} / \mathrm{mL}$ against $S$. mutans and S. sanguis, respectively. 
Amurensin G and 2-r-viniferin (Figure 18) inhibited the S. mutans adherence at sub-MIC concentrations (total bacterial adherence inhibition, TBAI $=25 \mu \mathrm{g} / \mathrm{mL}, \mathrm{MIC}=50 \mu \mathrm{g} / \mathrm{mL}$ ), which was consistent with the inhibitory activity on glucosyltransferases B and C (GTFs) exerted by the two compounds [109]. Indeed, GTFs synthesise the water-insoluble glucans, which mediate the sucrose-dependent adherence and accumulation of cariogenic streptococci [110]. Moreover, amurensin G showed a good inhibitory activity on the growth of both $S$. mutans and $S$. sanguis (MIC 50-12.5 $\mu \mathrm{g} / \mathrm{mL}$ ), whereas 2-r-viniferin was active only against $S$. mutans. Notably, $\varepsilon$-viniferin and amurensin $\mathrm{G}$ showed the same MIC as erythromycin [109].

Table 15. MIC, MBC, and total bacterial adherence inhibition (TBAI) of the compounds from V. amurensis from Yim et al. (2010) [109].

\begin{tabular}{|c|c|c|c|c|c|c|}
\hline \multirow{2}{*}{ Compound } & \multicolumn{3}{|c|}{ S. mutans } & \multicolumn{3}{|c|}{ S. sanguis } \\
\hline & $\begin{array}{c}\text { MIC } \\
(\mu \mathrm{g} / \mathrm{mL})\end{array}$ & $\begin{array}{c}\text { MBC } \\
(\mu \mathrm{g} / \mathrm{mL})\end{array}$ & $\begin{array}{c}\text { TBAI } \\
(\mu \mathrm{g} / \mathrm{mL})\end{array}$ & $\begin{array}{c}\text { MIC } \\
(\mu \mathrm{g} / \mathrm{mL})\end{array}$ & $\begin{array}{c}\text { MBC } \\
(\mu \mathrm{g} / \mathrm{mL})\end{array}$ & $\begin{array}{c}\text { TBAI } \\
(\mu \mathrm{g} / \mathrm{mL})\end{array}$ \\
\hline$\varepsilon$-Viniferin & 25 & 50 & 25 & 12.5 & 50 & 50 \\
\hline (+)-Ampelopsin A & 200 & 200 & 100 & $>400$ & $>400$ & $>400$ \\
\hline (+)-Ampelopsin F & 100 & 200 & 100 & $>400$ & $>400$ & $>400$ \\
\hline Amurensin $\mathrm{G}$ & 50 & 50 & 25 & 12.5 & 100 & 50 \\
\hline 2-r-Viniferin & 50 & 50 & 25 & 200 & 400 & 100 \\
\hline Erythromycin * & $<1.5$ & $<1.5$ & 0.78 & 12.5 & 50 & 25 \\
\hline
\end{tabular}

Cho et al. [111] demonstrated the anti-biofilm properties of $\varepsilon$-viniferin (Figure 16) against the Gram-negative P. aeruginosa PA14 (a clinical isolate) and PAO1, and E. coli O157:H7 (ATCC43895), which is associated with a high risk of hemolytic-uremic syndrome when infections are treated with antibiotics. In particular, $\varepsilon$-viniferin at $50 \mu \mathrm{g} / \mathrm{mL}$ inhibited P. aeruginosa PA14 biofilm formation by $82 \%$, and at $10 \mu \mathrm{g} / \mathrm{mL}$ inhibited E. coli O157: H7 biofilm formation by $98 \%$, without affecting planktonic cells growth, thus reducing the risk of antibiotic resistance. However, further studies are required to elucidate the mechanism of action, since it did not appear to be related to virulence factors production, including pyocyanin, rhamnolipid, and pyochelin by P. aeruginosa [111]. In another study [112], ( \pm )- $\varepsilon$-viniferin along with its stereoisomer $( \pm)-E$ - $\omega$-viniferin, the hydrogenated and the penta-methylated analogues (Figure 16), was tested on different S. pneumonia strains. $( \pm)-\varepsilon$-Viniferin was found to be the most active compound with an MIC value of $20 \mu \mathrm{M}$ even on antibiotic-resistant strains. Therefore, the activity of $( \pm)-\varepsilon$-viniferin as an anti-biofilm agent was evaluated. The compound did not show any activity at sub-MICs, but at MIC concentration, it prevented biofilm formation in all strains tested, in contrast to aminoglycoside antibiotics, which cause stress in bacteria at sub-MICs, inducing biofilm formation [113]. Moreover, $( \pm)$ - $\varepsilon$-viniferin inhibited bacteria and planktonic cells growth under biofilm, without a bactericidal effect. SEM analysis, crystal violet (CV) absorption assay, significantly increased release of total protein and genetic material (DNA and RNA), all supported alteration and lysis of bacteria cell membrane, thus suggested as the target of $( \pm)-\varepsilon$-viniferin [112]. $\delta$-Viniferin and pallidol (Figure 16) were investigated for their antibacterial activity in several studies. $\delta$-Viniferin showed interesting MIC values against the Gram-positive bacteria B. cereus, L. monocytogenes, and S. aureus, and against the Gram-negative E. coli, whereas pallidol was found to be inactive (Table 16) [114]. The presence of an efflux pump inhibitor significantly enhanced the activity against the Gram-negative bacterium, which was further confirmed by the increased susceptibility of the E. coli tolC (a key component of efflux systems in E. coli) deletion strain. Regarding the mechanism, $\delta$-viniferin was demonstrated to downregulate two ABC transporters involved in cell division and the transport of molecules across the membrane. Moreover, from in vitro experiments and molecular modeling, $\delta$-viniferin was found to be a strong inhibitor of DNA gyrase, replacing ATP from its binding site and thus preventing DNA replication [114]. 
Table 16. MIC values of $\delta$-viniferin from Mora-Pale et al. (2015) [114].

\begin{tabular}{cccccc}
\hline \multirow{2}{*}{ Compound } & \multicolumn{5}{c}{ MIC $(\mu \mathrm{g} / \mathrm{mL})$} \\
\cline { 2 - 6 } & B. cereus & L. monocytogenes & S. aureus & E. coli BL21 & E. coli BL21 $\Delta$ TolC \\
\hline$\delta$-Viniferin & 13.6 & 113.5 & 28.1 & $>113.5$ & 3.2 \\
$\delta$-Viniferin + inhibitor & 6.8 & 113.5 & 28.1 & 113.5 & 1.4 \\
\hline
\end{tabular}

Efflux pump inhibitors: Phe-Arg- $\beta$-naphtylamide (PABN, $48.1 \mu \mathrm{M})$ for E. coli, 1(1-naphtylmethyl)-piperazine (NMP, $449.1 \mu \mathrm{M})$ for B. cereus, reserpine $(16 \mu \mathrm{M})$ for L. monocytogenes, and piperine $(350 \mu \mathrm{M})$ for S. aureus.

In another study, $\delta$-viniferin and other resveratrol dimers, including viniferifuran and dehydro- $\delta$-viniferin (Figure 16), were found to display antimicrobial activity against a panel of Gram-positive bacteria, showing MIC values in the range of $1-16 \mu \mathrm{g} / \mathrm{mL}$, whereas none of the compounds was active against Gram-negative bacteria at low concentrations (Table 17). In particular, dehydro- $\delta$-viniferin, the most active compound, was demonstrated to display its activity against L. monocytogenes by membrane depolarisation and the loss of membrane integrity, leading to cytoplasmic membrane damage [36].

Table 17. MIC and MBC (in brackets) of resveratrol dimers against a panel of bacteria from Mattio et al. (2019) [36].

\begin{tabular}{|c|c|c|c|c|}
\hline \multirow{2}{*}{ Bacteria } & \multicolumn{4}{|c|}{ MIC (MBC) $(\mu \mathrm{g} / \mathrm{mL})$} \\
\hline & Viniferifuran & Dehydro- $\delta$-viniferin & $\delta$-Viniferin & Chlorexidine * \\
\hline \multicolumn{5}{|l|}{ Gram-positive } \\
\hline L. monocytogenes Scott A & $16(>512)$ & 2(16) & $16(128)$ & $8(32)$ \\
\hline S. aureus ATCC 25923 & $16(>512)$ & $2(16)$ & $16(512)$ & $32(128)$ \\
\hline E. faecium DSM 20477 & $8(>512)$ & $2(32)$ & $8(512)$ & $4(128)$ \\
\hline E. faecalis DSM 20478 & $8(512)$ & $4(64)$ & $16(512)$ & $8(128)$ \\
\hline B. cereus DSM 9378 & $4(128)$ & $1(16)$ & $4(256)$ & $8(16)$ \\
\hline Gram-negative & & & & \\
\hline P. aeruginosa ATCC 27853 & $128(>512)$ & $256(512)$ & $256(>512)$ & $32(64)$ \\
\hline E. coli DSM 682 & $256(>512)$ & $512(>512)$ & $256(>512)$ & $32(64)$ \\
\hline E. coli DSM 8579 & $256(>512)$ & $512(>512)$ & $256(512)$ & $32(32)$ \\
\hline S. enterica DSM 9386 & $256(>512)$ & $512(>512)$ & $256(512)$ & $32(32)$ \\
\hline P. hauseri DSM 30118 & $256(>512)$ & $512(512)$ & $256(512)$ & $32(32)$ \\
\hline
\end{tabular}

* Chlorexidine was used as positive control.

In 2020, in order to perform SAR studies, Catinella et al. [115] synthesised a series of simplified derivatives of dehydro- $\delta$-viniferin and viniferifuran by a systematic removal of the moieties linked to the benzofuran ring and evaluated the antibacterial activity against the foodborne pathogen Listeria monocytogenes Scott A (Figure 20). The simplified derivatives of dehydro- $\delta$-viniferin (63-65) demonstrated a significant loss of the antibacterial efficacy compared to the parent compound, suggesting in this case the importance of all three phenolic rings linked to the benzofuran core for the activity. Conversely, the structural simplification of viniferifuran (MIC $=16 \mu \mathrm{g} / \mathrm{mL}, \mathrm{MBC}>512 \mu \mathrm{g} / \mathrm{mL}$ ) led to compound 67 with improved activity ( $\mathrm{MIC}=8 \mu \mathrm{g} / \mathrm{mL} ; \mathrm{MBC}=64 \mu \mathrm{g} / \mathrm{mL}$ ) against $L$. monocytogenes, which is comparable to the standard chlorhexidine. These data confirmed that the shape, the geometry, and the relative position of the hydroxy groups on the aromatic rings significantly affect the antimicrobial potency [115]. 
<smiles>Oc1ccc(-c2oc3ccccc3c2-c2ccc(O)cc2)cc1</smiles>

63<smiles>Oc1ccc(-c2oc3cc(O)ccc3c2-c2ccc(O)cc2)cc1</smiles>

66<smiles>Oc1cc(O)cc(/C=C/c2ccc3oc(-c4ccc(Cl)cc4)cc3c2)c1</smiles>

64<smiles></smiles>

67<smiles>Oc1cc(O)cc(/C=C/c2ccc3occ(-c4cc(O)cc(O)c4)c3c2)c1</smiles><smiles>Oc1ccc(/C=C/c2cc(O)cc3occ(-c4cc(O)cc([18OH])c4)c23)cc1</smiles>

Figure 20. Structures of benzofuran derivatives of $\delta$ - and $\varepsilon$-viniferin from Catinella et al. (2020) [115].

\section{Combination Therapy}

A combination of antibiotics is an alternative strategy to fight antibiotic resistance, widening the antibacterial spectrum compared to the monotherapy. Bioactive adjuvants with weak or no antibacterial activity, such as efflux pump inhibitors, membrane permeabilisers, and bacterial enzyme inhibitors may increase the potency of primary antibiotics, such as the $\beta$-lactamase inhibitor clavulanic acid administered with amoxicillin. On the other hand, the combination of two or more antibiotics may act on multiple targets of pathogens, which are assumed to have more difficulty to resist to diverse attacks $[17,116]$. Nonetheless, additive or synergistic effects of the combination therapy may avoid undesirable side effects of individual antibiotics due to high dose regimens [117].

In 2012, resveratrol and 3,5-dihydroxy-4-isopropylstilbene (Figure 1) were tested in combination with ciprofloxacin and cefotaxime against the Gram-positive bacteria B. subtilis MTCC 2756 and S. aureus MTCC 902, and the Gram-negative bacteria E. coli MTCC 2622 and P. aeruginosa MTCC 2642 by checkerboard microdilution test (MDT) and time-kill-assay (TKA) [118]. Both compounds resulted to be synergistic with ciprofloxacin against either Gram-negative or Gram-positive bacteria, whereas they demonstrated additive effects with cefotaxime. Therefore, the combination with a fluoroquinolone broadened the antibacterial spectrum of stilbenoids, which are usually found to be inactive against Gram-negative and anaerobic bacteria, besides lowering the dose of ciprofloxacin [118].

Another study [119] showed promising results of the combination of resveratrol with benzoyl peroxide in in vitro experiments on Propionibacterium acnes, which is the causative agent of acne. Benzoyl peroxide is highly effective as an anti-acne agent, but its side effects limit its use. On the other hand, resveratrol inhibits the $P$. acnes growth with an MIC value of at least $50 \mu \mathrm{g} / \mathrm{mL}$, with low bactericidal activity. The combination treatment revealed a high initial antibacterial activity due to benzoyl peroxide, followed by the longer lasting inhibitory effects shown by resveratrol alone. By transmission electron microscopy, structural alteration of bacterial membranes was noted with intramembranous edema and the loss of extracellular fimbrial structures in the presence of resveratrol. Therefore, thanks to the $P$. acnes-enhanced susceptibility due to resveratrol bacterial membrane alteration, the combination treatment may reduce the side effects of benzoyl peroxide, allowing a lower concentration with respect to that used in the current treatment. However, it should be stressed that in vivo studies are still needed [119].

In a more recent study [120], resveratrol was found to display a synergistic activity with colistin, which belongs to polymixins, last-resort agents against severe infections by multidrug-resistant Gram-negative bacteria. Resveratrol alone was ineffective against all tested strains. However, checkerboard assays demonstrated a dose-dependent synergism between resveratrol (used at a 
concentration ranging from 8 to $128 \mu \mathrm{g} / \mathrm{mL}$ ) and colistin on colistin-resistant (COL-R) strains, including intrinsically resistant species such as $S$. marcescens and P. mirabilis (Table 18). Moreover, the time-kill assays revealed that the combination of resveratrol $(128 \mu \mathrm{g} / \mathrm{mL})$ with colistin $(2 \mu \mathrm{g} / \mathrm{mL})$ was bactericidal for 11 out of the 15 COL-R strains tested, whereas the bactericidal effect on the remaining strains required colistin at $0.5 \times \mathrm{MIC}$ or $1 \times \mathrm{MIC}$, except for $E$. coli FI-4531 that did not seem to be susceptible to the combination. The synergism mechanism remains unknown, but the susceptibility of COL-R strains and the lack of any synergistic activity of colistin-susceptible (COL-S) strains suggested that resveratrol may interact with the lipid A modification systems that are involved in the resistance of COL-R strains [120].

Table 18. Results of checkerboard assays of colistin in combination with resveratrol from Cannatelli et al. (2018) [120].

\begin{tabular}{|c|c|c|c|c|c|c|c|c|}
\hline \multirow{3}{*}{ Strains } & \multirow{3}{*}{ Phenotype } & \multicolumn{7}{|c|}{ Colistin MICs $(\mu \mathrm{g} / \mathrm{mL})$ at Different Resveratrol Concentrations $(\mu \mathrm{g} / \mathrm{mL})$} \\
\hline & & \multicolumn{7}{|c|}{ Resveratrol Concentration $(\mu \mathrm{g} / \mathrm{mL})$} \\
\hline & & 0 & 8 & 16 & 32 & 64 & 128 & 256 \\
\hline E. coli $\mathrm{LC} 711 / 14$ & COL-R & 8 & 4 & $2 *$ & 1 * & $0.25^{*}$ & $0.25 *$ & $0.125^{*}$ \\
\hline E. coli LC761/12 & COL-R & 4 & $0.5^{*}$ & 0.5 & 0.25 * & $0.125 *$ & $0.125 *$ & $0.125^{*}$ \\
\hline E. coli $\mathrm{FI}-4451$ & COL-R & 8 & 8 & 8 & 4 & 4 & 4 & 4 \\
\hline E. coli FI-4531 & COL-R & 8 & 4 & 4 & 4 & 4 & $2 *$ & $2 *$ \\
\hline E. coli $\mathrm{FI}-4592$ & COL-R & 8 & 4 & 4 & 4 & 4 & 4 & 4 \\
\hline E. coli LC902/14 & COL-R & 8 & 4 & 4 & 4 & 4 & $2 *$ & $2 *$ \\
\hline C. braakii CA-26 & COL-R & 8 & 4 & 4 & 4 & 4 & $2 *$ & $2 *$ \\
\hline S. maltophilia 157 & COL-R & 32 & 4 & $2 *$ & $1 *$ & $0.5 *$ & $0.125 *$ & $0.125 *$ \\
\hline E. cloacae CIP6085 & COL-R & 128 & 128 & $32 *$ & $8^{*}$ & $0.5^{*}$ & $0.25^{*}$ & $0.125^{*}$ \\
\hline K. pneumoniae KKBO-1 ${ }^{\mathrm{a}}$ & MDR/ COL-S & 0.5 & 0.5 & 0.5 & 0.5 & $0.5^{*}$ & 0.5 & 0.5 \\
\hline K. pneumoniae KKBO-4 & MDR/ COL-R & 64 & 64 & 64 & $16^{*}$ & $8 *$ & $4^{*}$ & $4^{*}$ \\
\hline K. pneumoniae KPB-1 ${ }^{\text {a }}$ & MDR/ COL-S & 0.5 & 0.5 & 0.5 & 0.5 & 0.5 & 0.5 & 0.5 \\
\hline K. pneumoniae КРB-2 & MDR/COL-R & 4 & 4 & 4 & 4 & 2 & 1 * & $0.5 *$ \\
\hline K. pneumoniae KK207-1 a & MDR/COL-S & 0.5 & 0.5 & 0.5 & 1 & 0.5 & 0.5 & 0.5 \\
\hline K. pneumoniae KK207-2 & MDR/COL-R & 64 & 64 & 64 & 64 & $4^{*}$ & $1^{*}$ & $0.5^{*}$ \\
\hline K. pneumoniae 6884 & MDR/ COL-R & 8 & 8 & 8 & 8 & $4^{*}$ & $1 *$ & $1 *$ \\
\hline K. pneumoniae KPFan b & COL-R & 32 & 32 & 16 & $8^{*}$ & $2 *$ & $1^{*}$ & $1 *$ \\
\hline K. pneumoniae KPGP1 b & COL-R & 32 & 32 & 32 & 32 & $2 *$ & $1 *$ & $1 *$ \\
\hline A. Baumanii N50 & MDR/COL-R & 64 & 64 & 64 & 64 & $8^{*}$ & $1 *$ & $1 *$ \\
\hline S. marcescens CCUG1647 ${ }^{\mathrm{T}}$ & COL-R & $>128$ & $>128$ & $>128$ & $>128$ & $16^{*}$ & $1 *$ & $1 *$ \\
\hline P. mirabilis NO-051 & COL-R & $>128$ & $>128$ & $>128$ & $>128$ & $>128$ & $>128$ & $8^{*}$ \\
\hline
\end{tabular}

a These strains were the colistin-susceptible (COL-S) precursors of colistin-resistant (COL-R) K. pneumoniae KKBO-4, K. pneumoniae KPB-2, and K. pneumoniae KK207-2 strains, respectively. Resveratrol MICs were $>512 \mathrm{mg} / \mathrm{L}$ for all tested strains. ${ }^{\mathrm{b}}$ These COL-R strains were selected in vitro, using two COL-S precursors. Multidrug-resistant phenotypes (MDR) refer to strains resistant to carbapenems (imipenem and meropenem), ciprofloxacin, and amikacin. * Combinations in which colistin/resveratrol combinations yielded a synergistic activity (FICI $\leq 0.5)$. The lower concentration of resveratrol needed for restoring susceptibility to colistin is shaded in gray.

Stilbenoid dimers and trimers were evaluated for their potential interaction with vancomycin and linezolid against MRSA strains (ATCC 33591 and HUKM strains) [121]. $\varepsilon$-Viniferin (Figure 16) reduced the MIC values of vancomycin by eightfold and 16-fold against ATCC and HUKM strains, respectively, demonstrating a synergistic effect. However, no synergistic interaction was observed between $\varepsilon$-viniferin and linezolid. Moreover, $\varepsilon$-viniferin resulted to antagonise the bactericidal activity of vancomycin, in spite of their synergistic bacteriostatic activity [121]. This finding may confirm $\varepsilon$-viniferin as a bacteriostatic anti-MRSA agent [117], since it has been already reported that a bactericidal agent is usually more efficient on multiplying bacteria [4]. Gnemonol B (Figure 18) exhibited a partial synergism with gentamycin against MRSA strains, and with ampicillin, gentamycin, micocycline, fosfomycin, or vancomycin against VRE strains. Gnetin E (Figure 18) was partially synergistic with gentamycin, minocycline, fosfomycin, and vancomycin against MRSA, and with gentamycin and vancomycin against VRE [103].

\section{Delivery Systems}

As showed in the previous paragraphs, stilbenoids exert antibacterial activity on several microorganisms with a variety of mechanisms of action. However, their industrial application 
as food preservatives or their use in clinical treatments have been limited by their poor availability and bioaccessibility, due to low water solubility, high metabolism, chemical instability, and interactions with food matrix such as proteins and fats [122-124]. Therefore, in the last years, efforts have been made to find delivery systems for stilbenoids, especially for resveratrol, for application as antibacterial agents in humans as well as preservatives in food and pharmaceutical packaging. A useful approach is the development of nanoparticles (NPs) as delivery systems [123,125]. Glaser et al. [126] combined the antimicrobial activity of chitosan, a polysaccharide biopolymer derived from the partial N-deacetylation of the natural chitin [127], and the antioxidant and antibacterial potency of resveratrol, to develop a coating for polyethylene (PE) and polypropylene (PP) polymer foils for pharmaceutical and food packaging [126]. The first layer consisting of $2 \%$ chitosan dispersion conferred antimicrobial properties, which are mainly due to the positively amino groups of chitosan [127], whereas the uppermost layer, containing nanoparticles of chitosan and resveratrol, enabled antioxidant and antibacterial activities. In particular, the obtained results showed that an antimicrobial efficacy (calculated as the percentage of reduction, which is the difference between the viable cells recovered after the incubation of untreated material and the viable cells recovered after the incubation of treated material) of more than $90 \%$ and $75 \%$ was achieved against $S$. aureus and E. coli, respectively [126]. In order to improve the low bioavailability of phenolic compounds, Vitonyte et al. [128] combined resveratrol and gallic acid in liposomes modified by the addition of a co-solvent, propylene glycol or glycerol, to produce Penetration Enhancer-containing Vesicles (PG-PEVs) and in glycerosomes as effective pharmaceutical tools against skin pathologies associated with oxidative stress and bacterial infections. The vesicles system formulation prevented the potential cytotoxic effect of high concentrations of the two active ingredients and improved cell viability after hydrogen peroxide-induced stress, in comparison to the effect of the dispersion of the phenols in water/glycerol blend (1/1). Overall, propylene glycol liposomes (PG-PEVs) and glycerosomes increased the total phenol accumulation in dermis. Indeed, glycerol promoted resveratrol penetration of the stratum corneum bilayer. On the other hand, phospholipid vesicles significantly enhanced the deposition of the hydrophilic gallic acid in the whole skin, as compared to the deposition obtained by the water/glycerol dispersion. Regarding the antimicrobial effects, all vesicle formulations showed good antibiofilm activity against Streptococcus intermedius and Streptococcus pyogenes (MBIC, minimum biofilm inhibition concentration $=312 \mu \mathrm{g} / \mathrm{mL}$ ) [128].

In 2015, Silva et al. [129] assessed the antimicrobial activity of pinosylvin and pterostilbene (Figure 1), encapsulated in cyclodextrin inclusion complexes (ICs), against Campylobacter jejuni and Campylobacter coli, causing bacterial foodborne diarrhoeal diseases. The study showed that pterostilbene as pure compound exerted no antibacterial activity against the reference strains (ATCC 33560 and ATCC 33559) and moderate activity on the clinical isolates C. jejuni 930/12 and C. coli 22/08 (MIC value $=50 \mu \mathrm{g} / \mathrm{mL}$ ). However, the pterostilbene ICs resulted in MIC values fivefold higher than those of the pure compound. Conversely, the antibacterial activity of pinosylvin as pure compound (MIC values ranging from 25 to $50 \mu \mathrm{g} / \mathrm{mL}$ ) was very similar to that exerted as IC (MIC values ranging from 16 to $64 \mu \mathrm{g} / \mathrm{mL})$. In particular, the value of the apparent stability constant $\left(\mathrm{K}_{\mathrm{S}}\right)$ of pterostilbene ICs was several orders of magnitude higher than that of pinosylvin ICs, indicating a more difficult dissociation of pterostilbene from the cyclodextrin complex, which is necessary for the antimicrobial compound to act inside the bacterial cell [130]. Investigating the pinosylvin ICs mechanism of action, the bacterial membrane was postulated to be the main target by four steps, including diffusion and collision of the IC with the membrane surface, followed by the complex dissociation and release of pinosylvin from the IC cavity and final diffusion through the bacterial membrane [131]. Furthermore, the pinosylvin ICs inhibited Campylobacter growth even at 4 and $20^{\circ} \mathrm{C}$, causing membrane depolarisation, increased permeability, and the inhibition of an efflux pumps system [129]. The effect of metallic nanoparticles on the antimicrobial activity of resveratrol and vice versa was also studied (Table 19) [132]. Gold nanoparticles (AuNPs) and silver nanoparticles (AgNPs) have demonstrated antibacterial properties through multifaceted mechanisms that are believed to avoid the bacterial resistance [133]. Therefore, novel nanoparticles carrying resveratrol on gold (Res-AuNPs) 
and on silver ions (Res-AgNPs-NaOH and Res-AgNPs-SDS, combined with sodium dodecyl sulfate) were developed and tested against 22 strains of Gram-positive and Gram-negative bacteria. The results showed that overall, resveratrol associated to all kind of metallic nanoparticles was more effective than resveratrol alone. The Res-AgNPs-SDS were twofold more potent than Res-AgNPs-NaOH against S. aureus (SG511, 285 and 503), E. coli DC 2, Klebsiella oxytoca 1082E, and S. pneumoniae. Streptococcus pneumoniae was the most sensitive microorganism, and the Res-AuPN nanocarriers further lowered the MIC value from 28.5 to $14.25 \mu \mathrm{g} / \mathrm{mL}$ [132]. Even if the antibacterial mechanism of these metallic nanocarriers still needs to be elucidated, several hypotheses have been proposed: (1) silver NPs bind to sulfhydryl and disulfide groups of bacterial membrane constituents, hampering cell wall synthesis; (2) positive charged metals electrostatically interact with the negative charged phospholipid bilayer of bacterial membranes, disrupting cell membrane potential and integrity; (3) metal NPs bind to DNA or to cytosolic proteins, such as enzymes involved in the respiratory chain and other metabolic pathways; and (4) metals from NPs can produce ROS, damaging DNA, proteins, and cell walls [133].

Table 19. MIC values of Res-AuNPs, Res-AgNPs-SDS, Res-AgNPs-NaOH, resveratrol standard, and norfloxacin, used as standard antibiotic from Park et al. (2016) [132].

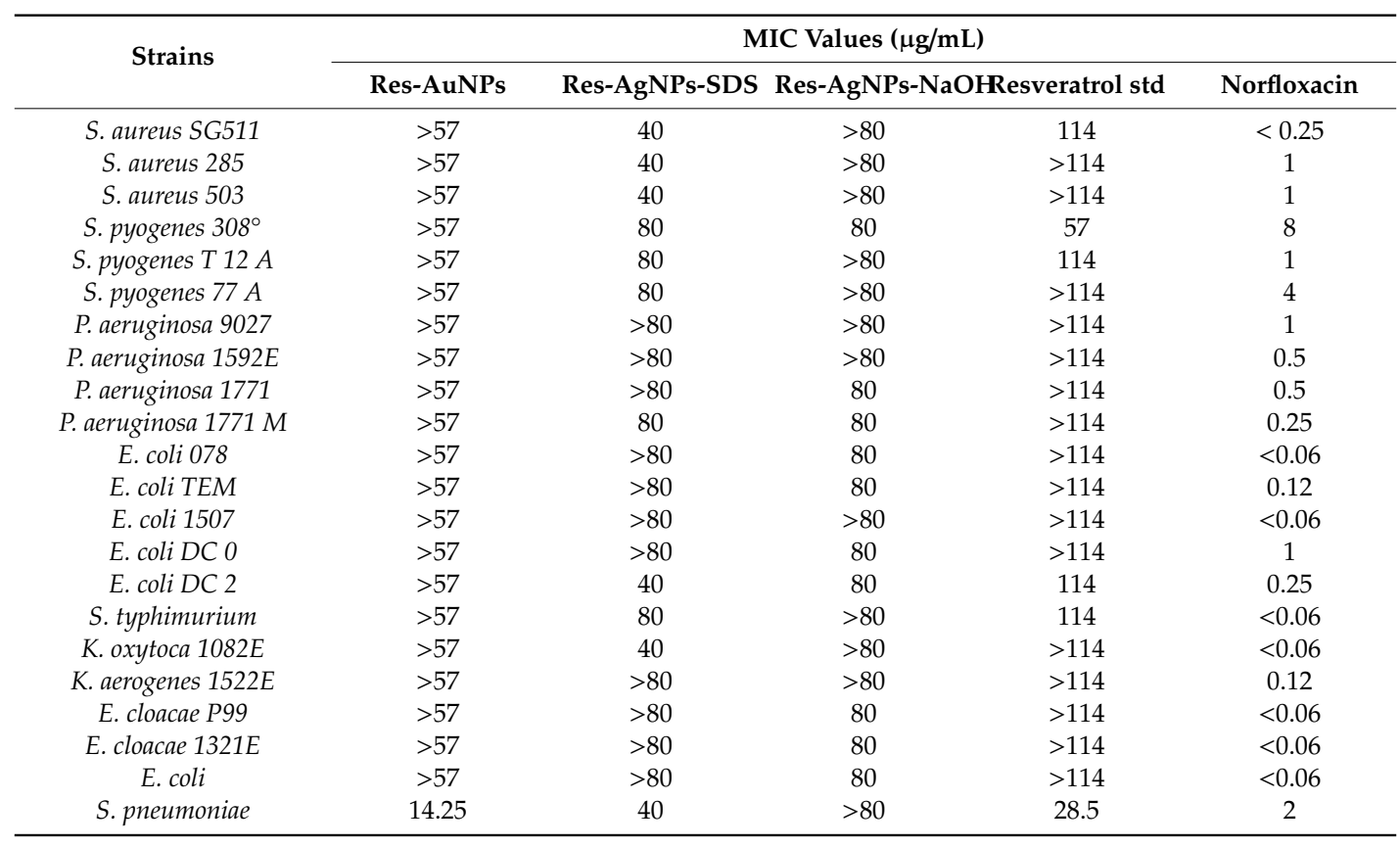

Resveratrol-biopolymers, deposited as thin, uniform, and adherent coatings through matrix-assisted pulsed laser evaporation (MAPLE), were prepared in order to incorporate the natural compound in bulk materials to avoid bacterial adhesion and subsequent infection [134]. The biopolymers were investigated for their antimicrobial efficiency against both Gram-positive and Gram-negative strains. The film consisting of resveratrol combined with PVP (polyvinylpyrrolidone) resulted to be effective against $S$. aureus strains, mainly by a contact-killing effect, which hampered initial bacterial adherence through physicochemical interactions or bactericidal effects on the planktonic cells. Biofilms containing only PVP showed activity similar to that of PVP-resveratrol combination, which was presumably because of the anti-fouling effect of PVP that guaranteed a hydrophilic environment, impeding the hydrophobic interactions necessary for the initial bacterial adhesion [134].

\section{Conclusions}

Stilbenoids represent a class of natural products endowed with several biological activities. Having evolved over several millennia to acquire specific ligand-protein binding motifs, these privileged scaffolds are biologically prevalidated platforms in the search for new active compounds. 
The most studied stilbenoid is resveratrol, which has received massive attention for its potential health benefits, including the management and prevention of infectious diseases. However, in recent years, also resveratrol-derived monomers, dimers, and oligomers have been extensively studied for their antimicrobial activity. The interest in the pharmacological potential of resveratrol-derived compounds has increased due to both poor bioavailability and incomplete understanding of the pharmacodynamics of resveratrol, which severely hamper its therapeutic applications. In this review, we have provided a summary of the most recent studies concerning the antimicrobial activity not only of the parent compound, but also of other natural stilbenoids, which in most cases were found to be more active than resveratrol itself. Synthetic approaches and SAR studies to give agents with better pharmacokinetic profiles and an improved spectrum of antimicrobial activity were reported as well. Despite the difficulties in comparing the obtained results, it is clear that resveratrol-derived stilbenoids possess promising activity, which has been mainly confirmed by in vitro studies. Nevertheless, a great effort to carry out in vivo experiments is still needed and remains of primary importance to confirm the antimicrobial potential of stilbenoids for future clinical applications.

Author Contributions: L.M.M. and G.C. prepared the original draft. A.P. and S.D. participated in the writing, review and editing. S.D. conceived the manuscript. G.C. and L.M.M. contributed equally to this work. All authors have read and agreed to the published version of the manuscript.

Funding: This research received no external funding.

Acknowledgments: Giorgia Catinella is grateful to Fondazione F.lli Confalonieri for PhD Scholarship.

Conflicts of Interest: The authors declare no conflict of interest.

\section{References}

1. Patridge, E.; Gareiss, P.; Kinch, M.S.; Hoyer, D. An analysis of FDA-approved drugs: Natural products and their derivatives. Drug Discov. Today 2016, 21, 204-207. [CrossRef]

2. Appendino, G.; Banfi, L. Molecular diversity and natural products. Mol. Divers. 2011, 15, 291-292. [CrossRef]

3. David, B.; Wolfender, J.L.; Dias, D.A. The pharmaceutical industry and natural products: Historical status and new trends. Phytochem. Rev. 2015, 14, 299-315. [CrossRef]

4. Lemke, T.L.; Williams, D.A.; Roche, V.F.; Zito, S.W. Foye's Principles of Medicinal Chemistry, 7th ed.; Lippincott Williams \& Wilkins: Philadelphia, PA, USA, 2013.

5. Newman, D.J.; Cragg, G.M. Natural products as sources of new drugs over the nearly four decades from 01/1981 to 09/2019. J. Nat. Prod. 2020, 83, 770-803. [CrossRef]

6. Akinwumi, B.C.; Bordun, K.A.M.; Anderson, H.D. Biological activities of stilbenoids. Int. J. Mol. Sci. 2018, 19, 792. [CrossRef] [PubMed]

7. Niesen, D.B.; Hessler, C.; Seeram, N.P. Beyond resveratrol: A review of natural stilbenoids identified from 2009-2013. J. Berry Res. 2013, 3, 181-196. [CrossRef]

8. Lu, D.; Zhao, W.; Zhao, S. Relevant enzymes, genes and regulation mechanisms in biosynthesis pathway of stilbenes. Open J. Med. Chem. 2012, 02, 15-23. [CrossRef]

9. Rivière, C.; Pawlus, A.D.; Mérillon, J.M. Natural stilbenoids: Distribution in the plant kingdom and chemotaxonomic interest in Vitaceae. Nat. Prod. Rep. 2012, 29, 1317-1333. [CrossRef] [PubMed]

10. Weiskirchen, S.; Weiskirchen, R. Resveratrol: How much wine do you have to drink to stay healthy? Adv. Nutr. 2016, 7, 706-718. [CrossRef]

11. Vestergaard, M.; Ingmer, H. Antibacterial and antifungal properties of resveratrol. Int. J. Antimicrob. Agents 2019, 53, 716-723. [CrossRef]

12. Ma, D.S.L.; Tan, L.T.H.; Chan, K.G.; Yap, W.H.; Pusparajah, P.; Chuah, L.H.; Ming, L.C.; Khan, T.M.; Lee, L.H.; Goh, B.H. Resveratrol-potential antibacterial agent against foodborne pathogens. Front. Pharmacol. 2018, 9, 1-16. [CrossRef]

13. Ferreira, S.; Silva, F.; Queiroz, J.A.; Oleastro, M.; Domingues, F.C. Resveratrol against Arcobacter butzleri and Arcobacter cryaerophilus: Activity and effect on cellular functions. Int. J. Food Microbiol. 2014, 180, 62-68. [CrossRef] 
14. Collado, L.; Figueras, M.J. Taxonomy, epidemiology, and clinical relevance of the genus Arcobacter. Clin. Microbiol. Rev. 2011, 24, 174-192. [CrossRef]

15. Bostanghadiri, N.; Pormohammad, A.; Chirani, A.S.; Pouriran, R.; Erfanimanesh, S.; Hashemi, A. Comprehensive review on the antimicrobial potency of the plant polyphenol resveratrol. Biomed. Pharmacother. 2017, 95, 1588-1595. [CrossRef]

16. Rasko, D.A.; Sperandio, V. Anti-virulence strategies to combat bacteria-mediated disease. Nat. Rev. Drug Discov. 2010, 9, 117-128. [CrossRef]

17. Domalaon, R.; Idowu, T.; Zhanel, G.G.; Schweizer, F. Antibiotic hybrids: The next generation of agents and adjuvants against gram-negative pathogens? Clin. Microbiol. Rev. 2018, 31, 1-45. [CrossRef]

18. Tang, F.; Li, L.; Meng, X.M.; Li, B.; Wang, C.Q.; Wang, S.Q.; Wang, T.L.; Tian, Y.M. Inhibition of alpha-hemolysin expression by resveratrol attenuates Staphylococcus aureus virulence. Microb. Pathog. 2019, 127, 85-90. [CrossRef]

19. O'Connell, K.M.G.; Hodgkinson, J.T.; Sore, H.F.; Welch, M.; Salmond, G.P.C.; Spring, D.R. Combating multidrug-resistant bacteria: Current strategies for the discovery of novel antibacterials. Angew. Chem. Int. Ed. 2013, 52, 10706-10733. [CrossRef] [PubMed]

20. Ferreira, S.; Domingues, F. The antimicrobial action of resveratrol against Listeria monocytogenes in food-based models and its antibiofilm properties. J. Sci. Food Agric. 2016, 96, 4531-4535. [CrossRef]

21. Kugaji, M.S.; Kumbar, V.M.; Peram, M.R.; Patil, S.; Bhat, K.G.; Diwan, P.V. Effect of Resveratrol on biofilm formation and virulence factor gene expression of Porphyromonas gingivalis in periodontal disease. Apmis 2019, 127, 187-195. [CrossRef]

22. Bao, K.; Belibasakis, G.N.; Thurnheer, T.; Aduse-Opoku, J.; Curtis, M.A.; Bostanci, N. Role of Porphyromonas gingivalis gingipains in multi-species biofilm formation. BMC Microbiol. 2014, 14, 1-8. [CrossRef]

23. Zaidi, S.F.H.; Ahmed, K.; Yamamoto, T.; Kondo, T.; Usmanghani, K.; Kadowaki, M.; Sugiyama, T. Effect of resveratrol on Helicobacter pylori-induced interleukin-8 secretion, reactive oxygen species generation and morphological changes in human gastric epithelial cells. Biol. Pharm. Bull. 2009, 32, 1931-1935. [CrossRef] [PubMed]

24. Nassiri-Asl, M.; Hosseinzadeh, H. Review of the pharmacological effects of Vitis vinifera (Grape) and its bioactive constituents: An update. Phyther. Res. 2016, 1403, 1392-1403. [CrossRef]

25. Brown, J.C.; Huang, G.; Haley-Zitlin, V.; Jiang, X. Antibacterial effects of grape extracts on helicobacter pylori. Appl. Environ. Microbiol. 2009, 75, 848-852. [CrossRef]

26. Paulo, L.; Oleastro, M.; Gallardo, E.; Queiroz, J.A.; Domingues, F. Anti-Helicobacter pylori and urease inhibitory activities of resveratrol and red wine. Food Res. Int. 2011, 44, 964-969. [CrossRef]

27. Guo, C.; Sinnott, B.; Niu, B.; Lowry, M.B.; Fantacone, M.L.; Gombart, A.F. Synergistic induction of human cathelicidin antimicrobial peptide gene expression by vitamin D and stilbenoids. Mol. Nutr. Food Res. 2014, 58, 528-536. [CrossRef] [PubMed]

28. Gombart, A.F.; Borregaard, N.; Koeffler, H.P. Human cathelicidin antimicrobial peptide (CAMP) gene is a direct target of the vitamin $\mathrm{D}$ receptor and is strongly up-regulated in myeloid cells by 1,25-dihydroxyvitamin D 3. FASEB J. 2005, 19, 1067-1077. [CrossRef] [PubMed]

29. Euba, B.; López-López, N.; Rodríguez-Arce, I.; Fernández-Calvet, A.; Barberán, M.; Caturla, N.; Martí, S.; Díez-Martínez, R.; Garmendia, J. Resveratrol therapeutics combines both antimicrobial and immunomodulatory properties against respiratory infection by nontypeable Haemophilus influenzae. Sci. Rep. 2017, 7, 1-14. [CrossRef]

30. Alikhan, M.M.; Lee, F.E.H. Understanding nontypeable Haemophilus influenzae and chronic obstructive pulmonary disease. Curr. Opin. Pulm. Med. 2014, 20, 159-164. [CrossRef]

31. Oliveira, A.R.; Domingues, F.C.; Ferreira, S. The influence of resveratrol adaptation on resistance to antibiotics, benzalkonium chloride, heat and acid stresses of Staphylococcus aureus and Listeria monocytogenes. Food Control 2017, 73, 1420-1425. [CrossRef]

32. Shen, T.; Wang, X.N.; Lou, H.X. Natural stilbenes: An overview. Nat. Prod. Rep. 2009, 26, 916-935. [CrossRef] [PubMed]

33. Zakova, T.; Rondevaldova, J.; Bernardos, A.; Landa, P.; Kokoska, L. The relationship between structure and in vitro antistaphylococcal effect of plant-derived stilbenes. Acta Microbiol. Immunol. Hung. 2018, 65, 467-476. [CrossRef] [PubMed] 
34. Cowan, M.M. Plant products as antimicrobial agents. Clin. Microbiol. Rev. 1999, 12, 564-582. [CrossRef] [PubMed]

35. Cai, Y.Z.; Sun, M.; Xing, J.; Luo, Q.; Corke, H. Structure-radical scavenging activity relationships of phenolic compounds from traditional Chinese medicinal plants. Life Sci. 2006, 78, 2872-2888. [CrossRef]

36. Mattio, L.M.; Dallavalle, S.; Musso, L.; Filardi, R.; Franzetti, L.; Pellegrino, L.; D’Incecco, P.; Mora, D.; Pinto, A.; Arioli, S. Antimicrobial activity of resveratrol-derived monomers and dimers against foodborne pathogens. Sci. Rep. 2019, 9, 19525. [CrossRef]

37. Singh, D.; Mendonsa, R.; Koli, M.; Subramanian, M.; Nayak, S.K. Antibacterial activity of resveratrol structural analogues: A mechanistic evaluation of the structure-activity relationship. Toxicol. Appl. Pharmacol. 2019, 367, 23-32. [CrossRef]

38. Kolouchová, I.; Mat'átková, O.; Paldrychová, M.; Kodeš, Z.; Kvasničková, E.; Sigler, K.; Čejková, A.; Šmidrkal, J.; Demnerová, K.; Masák, J. Resveratrol, pterostilbene, and baicalein: Plant-derived anti-biofilm agents. Folia Microbiol. Praha. 2018, 63, 261-272. [CrossRef]

39. Famuyiwa, S.O.; Ntumy, A.N.; Andrae-Marobela, K.; Yeboah, S.O. A new homoisoflavonoid and the bioactivities of some selected homoisoflavonoids from the inter-bulb surfaces of Scilla nervosa subsp. rigidifolia. S. Afr. J. Bot. 2013, 88, 17-22. [CrossRef]

40. Du Toit, K.; Kweyama, A.; Bodenstein, J. Anti-inflammatory and antimicrobial profiles of Scilla nervosa (Burch.) Jessop (Hyacinthaceae). S. Afr. J. Sci. 2011, 107, 1-5. [CrossRef]

41. Pham, D.Q.; Ba, D.T.; Dao, N.T.; Choi, G.J.; Vu, T.T.; Kim, J.C.; Giang, T.P.L.; Vu, H.D.; Le Dang, Q. Antimicrobial efficacy of extracts and constituents fractionated from Rheum tanguticum Maxim. ex Balf. rhizomes against phytopathogenic fungi and bacteria. Ind. Crops Prod. 2017, 108, 442-450. [CrossRef]

42. Välimaa, A.L.; Honkalampi-Hämäläinen, U.; Pietarinen, S.; Willför, S.; Holmbom, B.; von Wright, A. Antimicrobial and cytotoxic knotwood extracts and related pure compounds and their effects on food-associated microorganisms. Int. J. Food Microbiol. 2007, 115, 235-243. [CrossRef]

43. Kumar, S.N.; Siji, J.V.; Rajasekharan, K.N.; Nambisan, B.; Mohandas, C. Bioactive stilbenes from a Bacillus sp. N strain associated with a novel rhabditid entomopathogenic nematode. Lett. Appl. Microbiol. 2012, 54, 410-417. [CrossRef] [PubMed]

44. Sundar, L.; Chang, F.N. The role of guanosine-3', 5'-bis-pyrophosphate in mediating antimicrobial activity of the antibiotic 3,5-dihydroxy-4-ethyl-trans-stilbene. Antimicrob. Agents Chemother. 1992, 36, 2645-2651. [CrossRef] [PubMed]

45. Kumar, S.N.; Nambisan, B.; Sundaresan, A.; Mohandas, C.; Anto, R.J. Isolation and identification of antimicrobial secondary metabolites from Bacillus cereus associated with a rhabditid entomopathogenic nematode. Ann. Microbiol. 2014, 64, 209-218. [CrossRef]

46. Park, H.B.; Sampathkumar, P.; Perez, C.E.; Lee, J.H.; Tran, J.; Bonanno, J.B.; Hallem, E.A.; Almo, S.C.; Crawford, J.M. Stilbene epoxidation and detoxification in a Photorhabdus luminescens-nematode symbiosis. J. Biol. Chem. 2017, 292, 6680-6694. [CrossRef] [PubMed]

47. Nijampatnam, B.; Zhang, H.; Cai, X.; Michalek, S.M.; Wu, H.; Velu, S.E. Inhibition of Streptococcus mutans biofilms by the natural stilbene piceatannol through the inhibition of glucosyltransferases. ACS Omega 2018, 3, 8378-8385. [CrossRef]

48. Mattos-Graner, R.O.; Napimoga, M.H.; Fukushima, K.; Duncan, M.J.; Smith, D.J. Comparative analysis of Gtf isozyme production and diversity in isolates of Streptococcus mutans with different biofilm growth phenotypes. J. Clin. Microbiol. 2004, 42, 4586-4592. [CrossRef]

49. Sheng, J.Y.; Chen, T.T.; Tan, X.J.; Chen, T.; Jia, A.Q. The quorum-sensing inhibiting effects of stilbenoids and their potential structure-activity relationship. Bioorganic Med. Chem. Lett. 2015, 25, 5217-5220. [CrossRef]

50. Kuete, V.; Ango, P.Y.; Fotso, G.W.; Kapche, G.D.W.F.; Dzoyem, J.P.; Wouking, A.G.; Ngadjui, B.T.; Abegaz, B.M. Antimicrobial activities of the methanol extract and compounds from Artocarpus communis (Moraceae). BMC Complement. Altern. Med. 2011, 11. [CrossRef]

51. Aslam, S.N.; Stevenson, P.C.; Phythian, S.J.; Veitch, N.C.; Hall, D.R. Synthesis of cicerfuran, an antifungal benzofuran, and some related analogues. Tetrahedron 2006, 62, 4214-4226. [CrossRef]

52. Aslam, S.N.; Stevenson, P.C.; Kokubun, T.; Hall, D.R. Antibacterial and antifungal activity of cicerfuran and related 2-arylbenzofurans and stilbenes. Microbiol. Res. 2009, 164, 191-195. [CrossRef] [PubMed] 
53. Kohnen, S.; Franck, T.; Van Antwerpen, P.; Boudjeltia, K.Z.; Mouithys-Mickalad, A.; Deby, C.; Moguilevsky, N.; Deby-Dupont, G.; Lamy, M.; Serteyn, D. Resveratrol inhibits the activity of equine neutrophil myeloperoxidase by a direct interaction with the enzyme. J. Agric. Food Chem. 2007, 55, 8080-8087. [CrossRef] [PubMed]

54. Chapman, A.L.P.; Skaff, O.; Senthilmohan, R.; Kettle, A.; Davies, M.J. Hypobromous acid and bromamine production by neutrophils and modulation by superoxide. Biochem. J. 2009, 417, 773-781. [CrossRef] [PubMed]

55. Thomas, E.L. Myeloperoxidase, hydrogen peroxide, chloride antimicrobial system: Nitrogen-chlorine derivatives of bacterial components in bactericidal action against Escherichia coli. Infect. Immun. 1979, 23, 522-531. [CrossRef] [PubMed]

56. Davies, M.J.; Hawkins, C.L.; Pattison, D.I.; Rees, M.D. Mammalian heme peroxidases: From molecular mechanisms to health implications. Antioxidants Redox Signal. 2008, 10, 1199-1234. [CrossRef] [PubMed]

57. Davies, M.J.; Hawkins, C.L. The role of myeloperoxidase in biomolecule modification, chronic inflammation, and disease. Antioxid. Redox Signal. 2020, 32, 957-981. [CrossRef]

58. Cavallaro, A.; Ainis, T.; Bottari, C.; Fimiani, V. Effect of resveratrol on some activities of isolated and in whole blood human neutrophils. Physiol. Res. 2003, 52, 555-562.

59. Li, X.Z.; Wei, X.; Zhang, C.J.; Jin, X.L.; Tang, J.J.; Fan, G.J.; Zhou, B. Hypohalous acid-mediated halogenation of resveratrol and its role in antioxidant and antimicrobial activities. Food Chem. 2012, 135, 1239-1244. [CrossRef]

60. Ferré-Filmon, K.; Delaude, L.; Demonceau, A.; Noels, A.F. Catalytic methods for the synthesis of stilbenes with an emphasis on their phytoalexins. Coord. Chem. Rev. 2004, 248, 2323-2336. [CrossRef]

61. Guastavino, J.F.; Budén, M.E.; Rossi, R.A. Room-temperature and transition-metal-free Mizoroki-Heck-type reaction. Synthesis of E-stilbenes by photoinduced C-H functionalization. J. Org. Chem. 2014, 79, 9104-9111. [CrossRef]

62. Albert, S.; Horbach, R.; Deising, H.B.; Siewert, B.; Csuk, R. Synthesis and antimicrobial activity of (E) stilbene derivatives. Bioorganic Med. Chem. 2011, 19, 5155-5166. [CrossRef] [PubMed]

63. Yang, T.; Fang, L.; Rimando, A.M.; Sobolev, V.; Mockaitis, K.; Medina-Bolivar, F. A stilbenoid-specific prenyltransferase utilizes dimethylallyl pyrophosphate from the plastidic terpenoid pathway. Plant Physiol. 2016, 171, 2483-2498. [CrossRef] [PubMed]

64. Simons, R.; Gruppen, H.; Bovee, T.F.H.; Verbruggen, M.A.; Vincken, J.P. Prenylated isoflavonoids from plants as selective estrogen receptor modulators (phytoSERMs). Food Funct. 2012, 3, 810-827. [CrossRef] [PubMed]

65. Aisyah, S.; Gruppen, H.; Madzora, B.; Vincken, J.P. Modulation of isoflavonoid composition of Rhizopus oryzae elicited soybean (Glycine max) seedlings by light and wounding. J. Agric. Food Chem. 2013, 61, 8657-8667. [CrossRef] [PubMed]

66. Araya-Cloutier, C.; den Besten, H.M.W.; Aisyah, S.; Gruppen, H.; Vincken, J.P. The position of prenylation of isoflavonoids and stilbenoids from legumes (Fabaceae) modulates the antimicrobial activity against Gram positive pathogens. Food Chem. 2017, 226, 193-201. [CrossRef] [PubMed]

67. Araya-Cloutier, C.; Vincken, J.P.; Van De Schans, M.G.M.; Hageman, J.; Schaftenaar, G.; Den Besten, H.M.W.; Gruppen, H. QSAR-based molecular signatures of prenylated (iso)flavonoids underlying antimicrobial potency against and membrane-disruption in Gram positive and Gram negative bacteria. Sci. Rep. 2018, 8, 1-14. [CrossRef]

68. de Bruijn, W.J.C.; Araya-Cloutier, C.; Bijlsma, J.; de Swart, A.; Sanders, M.G.; de Waard, P.; Gruppen, H.; Vincken, J.P. Antibacterial prenylated stilbenoids from peanut (Arachis hypogaea). Phytochem. Lett. 2018, 28, 13-18. [CrossRef]

69. Wu, J.; Li, B.; Xiao, W.; Hu, J.; Xie, J.; Yuan, J.; Wang, L. Longistylin A, a natural stilbene isolated from the leaves of Cajanus cajan, exhibits significant anti-MRSA activity. Int. J. Antimicrob. Agents 2020, 55, 105821. [CrossRef]

70. Starks, C.M.; Williams, R.B.; Norman, V.L.; Rice, S.M.; O’Neil-Johnson, M.; Lawrence, J.A.; Eldridge, G.R. Antibacterial chromene and chromane stilbenoids from Hymenocardia acida. Phytochemistry 2014, 98, $216-222$. [CrossRef]

71. Yang, X.Z.; Tang, C.P.; Ye, Y. Stilbenoids from Stemona japonica. J. Asian Nat. Prod. Res. 2006, 8, 47-53. [CrossRef]

72. Yang, X.; Yang, J.; Xu, C.; Lv, J.; Wang, C.; Song, P. Antimicrobial stilbenoids from Bletilla yunnanensis. Chem. Nat. Compd. 2016, 52, 19-22. [CrossRef] 
73. Katerere, D.R.; Gray, A.I.; Nash, R.J.; Waigh, R.D. Phytochemical and antimicrobial investigations of stilbenoids and flavonoids isolated from three species of Combretaceae. Fitoterapia 2012, 83, 932-940. [CrossRef] [PubMed]

74. Jiang, S.; Chen, C.F.; Ma, X.P.; Wang, M.Y.; Wang, W.; Xia, Y.; Zhang, N.; Wu, M.K.; Pan, W.D. Antibacterial stilbenes from the tubers of Bletilla striata. Fitoterapia 2019, 138, 1-5. [CrossRef] [PubMed]

75. He, X.; Wang, X.; Fang, J.; Zhao, Z.; Huang, L.; Guo, H.; Zheng, X. Bletilla striata: Medicinal uses, phytochemistry and pharmacological activities. J. Ethnopharmacol. 2017, 195, 20-38. [CrossRef]

76. Liang, Q.L.; Lei, L.L.; Cui, X.; Zou, N.S.; Duan, J.A. Bioactive cis-stilbenoids from the tubers of Scirpus yagara. Fitoterapia 2013, 84, 170-173. [CrossRef] [PubMed]

77. Cirla, A.; Mann, J. Combretastatins: From natural products to drug discovery. Nat. Prod. Rep. 2003, 20, 558-564. [CrossRef] [PubMed]

78. Jain, D.; Jain, N.; Patel, V.; Singhal, S.; Jain, S. Synthesis, characterization and antimicrobial activity of novel substituted cis-stilbene derivatives. World J. Pharm. Pharm. Sci. 2015, 4, 1473-1491.

79. Miliovsky, M.; Svinyarov, I.; Mitrev, Y.; Evstatieva, Y.; Nikolova, D.; Chochkova, M.; Bogdanov, M.G. A novel one-pot synthesis and preliminary biological activity evaluation of cis-restricted polyhydroxy stilbenes incorporating protocatechuic acid and cinnamic acid fragments. Eur. J. Med. Chem. 2013, 66, 185-192. [CrossRef] [PubMed]

80. More, P.S.; Singh, S.G. Synthesis and characterization of some novel stilbene derivatives derived from substituted (phenyl acetic acid, benzaldehyde, amines) triethyl amine and thionyl chloride. Int. Lett. Chem. Phys. Astron. 2015, 43, 71-80. [CrossRef]

81. Sakaue, Y.; Domon, H.; Oda, M.; Takenaka, S.; Kubo, M.; Fukuyama, Y.; Okiji, T.; Terao, Y. Anti-biofilm and bactericidal effects of magnolia bark-derived magnolol and honokiol on Streptococcus mutans. Microbiol. Immunol. 2016, 60, 10-16. [CrossRef]

82. Solinski, A.E.; Ochoa, C.; Lee, Y.E.; Paniak, T.; Kozlowski, M.C.; Wuest, W.M. Honokiol-inspired analogs as inhibitors of oral bacteria. ACS Infect. Dis. 2018, 4, 118-122. [CrossRef] [PubMed]

83. Ochoa, C.; Solinski, A.E.; Nowlan, M.; Dekarske, M.M.; Wuest, W.M.; Kozlowski, M.C. A Bisphenolic Honokiol analog outcompetes oral antimicrobial agent cetylpyridinium chloride via a membrane-associated mechanism. ACS Infect. Dis. 2020, 6, 74-79. [CrossRef]

84. Pluta, K.; Morak-Młodawska, B.; Jeleń, M. Recent progress in biological activities of synthesized phenothiazines. Eur. J. Med. Chem. 2011, 46, 3179-3189. [CrossRef] [PubMed]

85. Sun, D.; Rosokha, S.V.; Kochi, J.K. Donor-acceptor (electronic) coupling in the precursor complex to organic electron transfer: Intermolecular and intramolecular self-exchange between phenothiazine redox centers. $J$. Am. Chem. Soc. 2004, 126, 1388-1401. [CrossRef] [PubMed]

86. Lai, R.Y.; Fabrizio, E.F.; Lu, L.; Jenekhe, S.A.; Bard, A.J. Synthesis, cyclic voltammetric studies, and electrogenerated chemiluminescence of a new donor-Acceptor molecule: 3,7-[bis[4-phenyl-2-quinolyl]]-10-methylphenothiazine. J. Am. Chem. Soc. 2001, 123, 9112-9118. [CrossRef] [PubMed]

87. Kanagalatha, R.; Rajakumar, P.; Selvi, C.S.S.; Mohan, N. Synthesis and antimicrobicidal activity of phenothiazinophanes: A new class of permanent fluorescence sensing stilbenophanes. Asian J. Chem. 2015, 27, 4373-4378. [CrossRef]

88. Rezaei-Seresht, E.; Salimi, A.; Mahdavi, B. Synthesis, antioxidant and antibacterial activity of azo dye-stilbene hybrid compounds. Pigment Resin Technol. 2018, 48. [CrossRef]

89. Iqbal, A.; Khan, Z.A.; Shahzad, S.A.; Usman, M.; Khan, S.A.; Fauq, A.H.; Bari, A.; Sajid, M.A. Synthesis of E-stilbene azomethines as potent antimicrobial and antioxidant agents. Turk. J. Chem. 2018, 42, 1518-1533. [CrossRef]

90. Piotto, S.; Concilio, S.; Sessa, L.; Porta, A.; Calabrese, E.C.; Zanfardino, A.; Varcamonti, M.; Iannelli, P. Small azobenzene derivatives active against bacteria and fungi. Eur. J. Med. Chem. 2013, 68, 178-184. [CrossRef]

91. Garner, L.E.; Park, J.; Dyar, S.M.; Chworos, A.; Sumner, J.J.; Bazan, G.C. Modification of the optoelectronic properties of membranes via insertion of amphiphilic phenylenevinylene oligoelectrolytes. J. Am. Chem. Soc. 2010, 132, 10042-10052. [CrossRef]

92. Zhou, C.; Chia, G.W.N.; Ho, J.C.S.; Seviour, T.; Sailov, T.; Liedberg, B.; Kjelleberg, S.; Hinks, J.; Bazan, G.C. Informed molecular design of conjugated oligoelectrolytes to increase cell affinity and antimicrobial activity. Angew. Chem. Int. Ed. 2018, 57, 8069-8072. [CrossRef] [PubMed] 
93. Wan, M.; Hua, L.; Zeng, Y.; Jiao, P.; Xie, D.; Tong, Z.; Wu, G.; Zhou, Y.; Tang, Q.; Mo, F. Synthesis and properties of novel stilbene-twelve alkyl quaternary ammonium salts as antibacterial optical whitening agents. Cellulose 2017, 24, 3209-3218. [CrossRef]

94. Chanawanno, K.; Chantrapromma, S.; Anantapong, T.; Kanjana-Opas, A.; Fun, H.K. Synthesis, structure and in vitro antibacterial activities of new hybrid disinfectants quaternary ammonium compounds: Pyridinium and quinolinium stilbene benzenesulfonates. Eur. J. Med. Chem. 2010, 45, 4199-4208. [CrossRef] [PubMed]

95. Saeed, A.; Shabir, G.; Batool, I. Novel stilbene-triazine symmetrical optical brighteners: Synthesis and applications. J. Fluoresc. 2014, 24, 1119-1127. [CrossRef]

96. Kabir, M.S.; Engelbrecht, K.; Polanowski, R.; Krueger, S.M.; Ignasiak, R.; Rott, M.; Schwan, W.R.; Stemper, M.E.; Reed, K.D.; Sherman, D.; et al. New classes of Gram-positive selective antibacterials: Inhibitors of MRSA and surrogates of the causative agents of anthrax and tuberculosis. Bioorganic Med. Chem. Lett. 2008, 18, 5745-5749. [CrossRef]

97. Tang, K.W.; Yang, S.C.; Tseng, C.H. Design, synthesis, and anti-bacterial evaluation of triazolyl-pterostilbene derivatives. Int. J. Mol. Sci. 2019, 20, 4564. [CrossRef]

98. Yang, S.C.; Tseng, C.H.; Wang, P.W.; Lu, P.L.; Weng, Y.H.; Yen, F.L.; Fang, J.Y. Pterostilbene, a methoxylated resveratrol derivative, efficiently eradicates planktonic, biofilm, and intracellular MRSA by topical application. Front. Microbiol. 2017, 8, 1103. [CrossRef]

99. Agalave, S.G.; Maujan, S.R.; Pore, V.S. Click chemistry: 1,2,3-triazoles as pharmacophores. Chem. Asian J. 2011, 6, 2696-2718. [CrossRef]

100. Keylor, M.H.; Matsuura, B.S.; Stephenson, C.R.J. Chemistry and biology of resveratrol-derived natural products. Chem. Rev. 2015, 115, 8976-9027. [CrossRef]

101. Sáez, V.; Pastene, E.; Vergara, C.; Mardones, C.; Hermosín-Gutiérrez, I.; Gómez-Alonso, S.; Gómez, M.V.; Theoduloz, C.; Riquelme, S.; von Baer, D. Oligostilbenoids in Vitis vinifera L. Pinot Noir grape cane extract: Isolation, characterization, in vitro antioxidant capacity and anti-proliferative effect on cancer cells. Food Chem. 2018, 265, 101-110. [CrossRef]

102. Sakagami, Y. Anti-MRSA and anti-VRE activities of phytoalexins and phytoncides isolated from tropical plants. Mod. Phytomedicine 2006, 137-155. [CrossRef]

103. Sakagami, Y.; Sawabe, A.; Komemushi, S.; Ali, Z.; Tanaka, T.; Iliya, I.; Iinuma, M. Antibacterial activity of stilbene oligomers against vancomycin-resistant enterococci (VRE) and methicillin-resistant Staphylococcus aureus (MRSA) and their synergism with antibiotics. Biocontrol Sci. 2007, 12, 7-14. [CrossRef] [PubMed]

104. Peng, S.C.; Cheng, C.Y.; Sheu, F.; Su, C.H. The antimicrobial activity of heyneanol A extracted from the root of taiwanese wild grape. J. Appl. Microbiol. 2008, 105, 485-491. [CrossRef] [PubMed]

105. Zetterström, C.E.; Hasselgren, J.; Salin, O.; Davis, R.A.; Quinn, R.J.; Sundin, C.; Elofsson, M. The resveratrol tetramer (-)-hopeaphenol inhibits type III secretion in the gram-negative pathogens Yersinia pseudotuberculosis and Pseudomonas aeruginosa. PLoS ONE 2013, 8, e81969. [CrossRef] [PubMed]

106. Hueck, C.J. Type III protein secretion systems in bacterial pathogens of animals and plants. Microbiol. Mol. Biol. Rev. 1998, 62, 379-433. [CrossRef] [PubMed]

107. Lee, K.; Lee, J.H.; Ryu, S.Y.; Cho, M.H.; Lee, J. Stilbenes reduce Staphylococcus aureus hemolysis, biofilm formation, and virulence. Foodborne Pathog. Dis. 2014, 11, 710-717. [CrossRef] [PubMed]

108. Sahidin, I.; Wahyuni, W.; Malaka, M.H.; Imran, I. Antibacterial and cytotoxic potencies of stilbene oligomers from stem barks of baoti (Dryobalanops lanceolata) growing in Kendari, Indonesia. Asian J. Pharm. Clin. Res. 2017, 10, 139-143. [CrossRef]

109. Yim, N.H.; Ha, D.T.; Trung, T.N.; Kim, J.P.; Lee, S.M.; Na, M.K.; Jung, H.J.; Kim, H.S.; Kim, Y.H.; Bae, K.H. The antimicrobial activity of compounds from the leaf and stem of Vitis amurensis against two oral pathogens. Bioorganic Med. Chem. Lett. 2010, 20, 1165-1168. [CrossRef] [PubMed]

110. Duarte, S.; Koo, H.; Bowen, W.H.; Hayacibara, M.F.; Cury, J.A.; Ikegaki, M.; Rosalen, P.L. Effect of a novel type of propolis and its chemical fractions on glucosyltransferases and on growth and adherence of mutans streptococci. Biol. Pharm. Bull. 2003, 26, 527-531. [CrossRef]

111. Cho, H.S.; Lee, J.H.; Ryu, S.Y.; Joo, S.W.; Cho, M.H.; Lee, J. Inhibition of Pseudomonas aeruginosa and Escherichia coli O157:H7 Biofilm formation by plant metabolite $\varepsilon$-viniferin. J. Agric. Food Chem. 2013, 61, 7120-7126. [CrossRef] 
112. Yadav, M.K.; Mailar, K.; Masagalli, J.N.; Chae, S.W.; Song, J.J.; Choi, W.J. Ruthenium Chloride-induced oxidative cyclization of trans-Resveratrol to ( \pm )-Viniferin and antimicrobial and antibiofilm activity against Streptococcus pneumoniae. Front. Pharmacol. 2019, 10, 1-15. [CrossRef] [PubMed]

113. Hoffman, L.R.; D'Argenio, D.A.; MacCoss, M.J.; Zhang, Z.; Jones, R.A.; Miller, S.I. Aminoglycoside antibiotics induce bacterial biofilm formation. Nature 2005, 436, 1171-1175. [CrossRef] [PubMed]

114. Mora-Pale, M.; Bhan, N.; Masuko, S.; James, P.; Wood, J.; Mccallum, S.; Linhardt, R.J.; Dordick, J.S.; Koffas, M.A.G. Antimicrobial mechanism of resveratrol-trans-dihydrodimer produced from peroxidase-catalyzed oxidation of resveratrol. Biotechnol. Bioeng. 2015, 112, 2417-2428. [CrossRef] [PubMed]

115. Catinella, G.; Mattio, L.M.; Musso, L.; Arioli, S.; Mora, D.; Beretta, G.L.; Za, N.; Pinto, A.; Dallavalle, S. Structural requirements of benzofuran derivatives dehydro- $\delta$ - and dehydro- $\varepsilon$-viniferin for antimicrobial activity against the foodborne pathogen Listeria monocytogenes. Int. J. Mol. Sci. 2020, 21, 2168. [CrossRef]

116. Belley, A.; Neesham-Grenon, E.; Arhin, F.F.; McKay, G.A.; Parr, T.R.; Moeck, G. Assessment by time-kill methodology of the synergistic effects of oritavancin in combination with other antimicrobial agents against Staphylococcus aureus. Antimicrob. Agents Chemother. 2008, 52, 3820-3822. [CrossRef]

117. Basri, D.F.; Luoi, C.K.; Azmi, A.M.; Latip, J. Evaluation of the combined effects of stilbenoid from Shorea gibbosa and vancomycin against methicillin-resistant Staphylococcus aureus (MRSA). Pharmaceuticals 2012, 5, 1032-1043. [CrossRef] [PubMed]

118. Kumar, S.N.; Siji, J.V.; Nambisan, B.; Mohandas, C. Activity and synergistic interactions of stilbenes and antibiotic combinations against bacteria in vitro. World J. Microbiol. Biotechnol. 2012, 28,3143-3150. [CrossRef] [PubMed]

119. Taylor, E.J.M.; Yu, Y.; Champer, J.; Kim, J. Resveratrol demonstrates antimicrobial effects against Propionibacterium acnes in vitro. Dermatol. Ther. Heidelb. 2014, 4, 249-257. [CrossRef] [PubMed]

120. Cannatelli, A.; Principato, S.; Colavecchio, O.L.; Pallecchi, L.; Rossolini, G.M. Synergistic activity of colistin in combination with resveratrol against colistin-resistant gram-negative pathogens. Front. Microbiol. 2018, 9. [CrossRef]

121. Basri, D.F.; Xian, L.W.; Abdul Shukor, N.I.; Latip, J. Bacteriostatic antimicrobial combination: Antagonistic interaction between epsilon-viniferin and vancomycin against methicillin-resistant Staphylococcus aureus. Biomed Res. Int. 2014, 2014. [CrossRef]

122. Neves, A.R.; Lúcio, M.; Martins, S.; Lima, J.L.C.; Reis, S. Novel resveratrol nanodelivery systems based on lipid nanoparticles to enhance its oral bioavailability. Int. J. Nanomed. 2013, 8, 177-187. [CrossRef]

123. Hu, B.; Liu, X.; Zhang, C.; Zeng, X. Food macromolecule based nanodelivery systems for enhancing the bioavailability of polyphenols. J. Food Drug Anal. 2017, 25, 3-15. [CrossRef] [PubMed]

124. Davidov-Pardo, G.; Pérez-Ciordia, S.; Marín-Arroyo, M.R.; McClements, D.J. Improving resveratrol bioaccessibility using biopolymer nanoparticles and complexes: Impact of protein-carbohydrate Maillard conjugation. J. Agric. Food Chem. 2015, 63, 3915-3923. [CrossRef] [PubMed]

125. Li, Z.; Jiang, H.; Xu, C.; Gu, L. A review: Using nanoparticles to enhance absorption and bioavailability of phenolic phytochemicals. Food Hydrocoll. 2015, 43, 153-164. [CrossRef]

126. Glaser, T.K.; Plohl, O.; Vesel, A.; Ajdnik, U.; Ulrih, N.P.; Hrncic, M.K.; Bren, U.; Zemljǐ, L.F. Functionalization of polyethylene (PE) and polypropylene (PP) material using chitosan nanoparticles with incorporated resveratrol as potential active packaging. Materials 2019, 12, 2118. [CrossRef]

127. Raafat, D.; Von Bargen, K.; Haas, A.; Sahl, H.G. Insights into the mode of action of chitosan as an antibacterial compound. Appl. Environ. Microbiol. 2008, 74, 3764-3773. [CrossRef]

128. Vitonyte, J.; Manca, M.L.; Caddeo, C.; Valenti, D.; Peris, J.E.; Usach, I.; Nacher, A.; Matos, M.; Gutiérrez, G.; Orrù, G.; et al. Bifunctional viscous nanovesicles co-loaded with resveratrol and gallic acid for skin protection against microbial and oxidative injuries. Eur. J. Pharm. Biopharm. 2017, 114, 278-287. [CrossRef]

129. Silva, F.; Nerín, C.; Domingues, F.C. Stilbene phytoallexins inclusion complexes: A natural-based strategy to control foodborne pathogen Campylobacter. Food Control 2015, 54, 66-73. [CrossRef]

130. Leclercq, L.; Nardello-Rataj, V.; Rauwel, G.; Aubry, J.M. Structure-activity relationship of cyclodextrin/biocidal double-tailed ammonium surfactant host-guest complexes: Towards a delivery molecular mechanism? Eur. J. Pharm. Sci. 2010, 41, 265-275. [CrossRef]

131. Lu, Q.; Zhao, J.; Wang, M.; Wang, Z. Electrochemical evaluation of the controlled release behaviors of the cyclodextrin inclusion complexes on the drug deliveries to microbial cell. Int. J. Electrochem. Sci. 2011, 6, 3868-3877. 
132. Park, S.; Cha, S.H.; Cho, I.; Park, S.; Park, Y.; Cho, S.; Park, Y. Antibacterial nanocarriers of resveratrol with gold and silver nanoparticles. Mater. Sci. Eng. C 2016, 58, 1160-1169. [CrossRef] [PubMed]

133. Gold, K.; Slay, B.; Knackstedt, M.; Gaharwar, A.K. Antimicrobial activity of metal and metal-oxide based nanoparticles. Adv. Ther. 2018, 1, 1700033. [CrossRef]

134. Cristescu, R.; Visan, A.; Socol, G.; Surdu, A.V.; Oprea, A.E.; Grumezescu, A.M.; Chifiriuc, M.C.; Boehm, R.D.; Yamaleyeva, D.; Taylor, M.; et al. Antimicrobial activity of biopolymeric thin films containing flavonoid natural compounds and silver nanoparticles fabricated by MAPLE: A comparative study. Appl. Surf. Sci. 2016, 374, 290-296. [CrossRef]

(C) 2020 by the authors. Licensee MDPI, Basel, Switzerland. This article is an open access article distributed under the terms and conditions of the Creative Commons Attribution (CC BY) license (http://creativecommons.org/licenses/by/4.0/). 